\title{
Hierarchies of knowledge: ethnobotanical knowledge, practices and beliefs of the Vhavenda in South Africa for biodiversity conservation
}

\author{
Natasha Louise Constant ${ }^{1,2^{*}}$ (D) and Milingoni Peter Tshisikhawe ${ }^{3}$
}

\begin{abstract}
Background: Indigenous and local knowledge systems are characterised by a 'knowledge-practice-belief' complex that plays a critical role for biodiversity management and conservation on indigenous lands. However, few studies take into consideration the interconnected relationship between the social processes underpinning knowledge accumulation, generation and transmission. The study draws on ethnobotanical research to explore plant uses, practices and belief systems developed among the indigenous Vhavenda in South Africa for sustaining indigenous plant resources and highlights some of the forces of change influencing the acquisition and transmission of knowledge.

Methods: Data was collected from September-November 2016 from 31 individuals by means of semi-structured interviews; walks in home gardens, cultivated fields, montane forests and deciduous woodlands; and vouchering of plant species in six villages (Duthuni, Tshidzivhe, Vuvha, Lwamondo, Mashau and Tshiendeulu) in the Vhembe District of South Africa. The Use Value Index (UVI) was used to measure the number of different uses of each species and the Relative Frequency Index (RFI) to measure the local importance of each species. Semi-structured interviews and comparisons with published works also explored cultural practices and belief systems associated with plants, modes and barriers of knowledge transmission.

Results: Eighty-four plant species were reported within 44 families, with Fabaceae representing the highest diversity of plant species. We identified six species not previously documented in the Vhavenda ethnobotanical literature, 68 novel uses of plants and another 14 variations of known uses. Vhavenda plants were predominantly used for food (36.0\%) and medicine (26.1\%) and consisted mainly of native (73.8\%) compared to non-native species (26.2\%). The Vhavenda possess a range of practices for managing plant resources that can be attributed to taboos preventing the use of selected species, promotion of sustainable harvesting practices and the propagation of plant species for ecological restoration. Plant knowledge and management practices were transmitted from relatives (48.4\%), self-taught through time spent planting and harvesting plants on the land (19.4\%), through apprenticeships with traditional healers (16.1\%), initiation schools (9. 7\%) and clan gatherings (6.4\%). Changes in traditional learning platforms for knowledge exchange, erosion of cultural institutions and shifting value systems serve as barriers for knowledge transmission among the Vhavenda.

(Continued on next page)
\end{abstract}

\footnotetext{
* Correspondence: constantn@cardiff.ac.uk

'SARChl Chair on Biodiversity Value and Change, School of Mathematical and Natural Sciences, University of Venda, Private Bag X5050, Thohoyandou 0950, South Africa

${ }^{2}$ Sustainable Places Research Institute, Cardiff University, 33 Park Place, Cardiff CF10 3BA, UK

Full list of author information is available at the end of the article
}

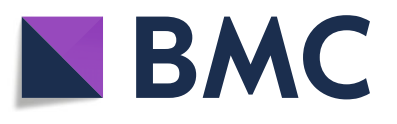

(c) The Author(s). 2018 Open Access This article is distributed under the terms of the Creative Commons Attribution 4.0 International License (http://creativecommons.org/licenses/by/4.0/), which permits unrestricted use, distribution, and reproduction in any medium, provided you give appropriate credit to the original author(s) and the source, provide a link to the Creative Commons license, and indicate if changes were made. The Creative Commons Public Domain Dedication waiver (http://creativecommons.org/publicdomain/zero/1.0/) applies to the data made available in this article, unless otherwise stated. 
(Continued from previous page)

Conclusion: The study points to a need for new partnerships to be forged between conservationists, government actors and local and indigenous knowledge holders to foster hybrid knowledge coproduction for developing strategies to enhance the productivity and biodiversity of indigenous lands.

Keywords: Ethnobotany, Indigenous and local knowledge, Traditional ecological knowledge, Biodiversity conservation, Sustainable management, Vhavenda, Knowledge transmission

\section{Background}

Indigenous and local communities have devised cultural practices embedded in cultural and religious values that have maintained species and habitats of biocultural importance through indigenous and local knowledge systems [1]. Indigenous and Local Knowledge (ILK) consist of a body of knowledge shaped by cultural practices, institutions and worldviews forming a nested 'knowledge-practice-belief' complex that provide insights into ways of knowing and governing social-ecological systems (SESs) for contemporary biodiversity management and conservation [1]. Indigenous plants provide a plethora of ecosystem services to support human needs for food, medicines, livelihoods and other cultural activities [2]. Plant resources are sustained through cultural practices where plant users collect and harvest materials selectively using locally adapted management strategies [3], that is also important for the conservation of biodiversity, rare species, ecological processes and sustainable harvesting practices $[1,4]$. The application of biodiversity management through cultural practices can help to strengthen cultural values compatible with conservation to sustain plant resources for biodiversity and to support human needs [5]. In recognition of this, many international and national agencies and agreements (e.g. Convention of Biological Diversity (CBD), Intergovernmental Platform on Biodiversity and Ecosystem Services (IPBES)) advocate for enhanced engagement and protection of the customary use of biogenetic resources in accordance with cultural practices to promote biodiversity conservation and sustainable use of natural resources.

Cultural practices are embedded in institutions and local social norms that influence the coordination and management of resource use practices often through traditional leaders who control access and use of natural resources on indigenous lands [4]. Taboos play a role in limiting destruction of important plant resources through limitations on harvesting and prohibitions against the use of selected species. Rituals, ceremonies and other traditions associated with plant use serve to pass on institutional memory and cultural internalisation to support knowledge generation, accumulation and transmission [4]. Similarly, worldviews are important for delineating beliefs, and cosmologies that influence cultural values, and ethics for engaging with the natural world [4]. These social mechanisms are critical for understanding how institutions and norms structure and transmit plant-based knowledge and influence modes of knowledge transmission to support the revival of sustainable management practices for biodiversity conservation.

The aim of the study is to examine the use, cultural practices and beliefs associated with plant species among a rural community in South Africa for biodiversity conservation on communal lands using a case study of the Vhavenda. Ethnobotanical research on the Vhavenda has focused on people's use and knowledge of indigenous plants [6], plants for food [7], nutrition [8], medicine [9-11], the treatment of livestock diseases [12], beverages [13], invasive species $[14,15]$ and impacts of bark harvesting [10]. Some studies have addressed the role of Vhavenda culture and conservation of the wider bio-physical environment [16] and the protection of sacred sites [17]. However, few studies have examined the interconnected relationships between plant-based knowledge, practices and beliefs of diverse plant species for biodiversity conservation and the nature and barriers of knowledge transmission in the context of social-cultural change. The hypothesis of the study is that the Vhavenda exhibit a complex 'knowledge-practice-belief' system of ILK that acts to sustain plant resources and carries insights to inform culturally specific management strategies for the conservation of indigenous plants on community lands. The study aims to address the following questions: (1) What are the characteristics of plant species used by the Vhavenda and which species are most important in terms of their use value and frequency of use? (2) What cultural practices, institutions and beliefs sustain plant resources for biodiversity conservation? and (3) How is plant-based knowledge acquired and what are the barriers for the transmission of knowledge to younger generations?

\section{Methods}

\section{Vhavenda history and social structure}

Oral accounts of the early history of the Vhavenda prior to their entry from present day Zimbabwe are vague and fragmented; however, it is probable that their origins were located in the Great Lakes region of East Africa [18]. The Vhavenda are composed of different clans, for example, Senzi, Nyai, Mbedzi, Lemba, Ngona, Ludzi, Kwevho, Nzhelele, Luvhu, Famadi and other smaller 
nuclear groups [19]. The first Europeans arrived in Venda during the early 1800 s including missionaries, explorers, hunters and land speculation companies. Contestations between the Vhavenda and the first colonisers (named the Voortrekkers) ensued over conflicts of land and natural resource resulting in ongoing wars between the late 1880s-1900s [20]. The first missionary church was established in the region named Schoemansdal in 1851 [17]. The missionaries acted as neutral entities during the earlier colonial wars but asserted their own form of colonisation through the erosion of traditional cultural practices and belief systems of the Vhavenda.

The onset of apartheid headed by the National Party saw the establishment of the Bantustans where South Africans were segregated by ethnicity to create territories and 'autonomous' national states [17]. The Prime Minister of the time Verwoerd sought to reduce the number of Africans resident in South Africa's urban areas by requiring them to live in their respective homelands and to seek employment in nearby towns and cities to address rural poverty [21]. Vhavenda chiefs who were ruling at the time favoured the new government policy mainly because they were able to maintain their traditional system of governance [22]. In 1973, Vhavenda was granted self-government under the leadership of Chief Patrick Mphephu who traced his ancestry to the legendary leader Thohoyandou [23].

The current social structure of the Vhavenda chieftainship is headed by the Thovhele meaning 'king' who rules over the largest regions of Vhavenda [21]. The Khosi, a 'senior chief,' rules an area of more than two villages, and under his jurisdiction, each village is ruled by a Vhamusanda, a junior chief [19]. A Vhamusanda may appoint a Mukoma who settles disputes in the village and is responsible for allocating arable land to individual homesteads, organising social rituals, and the protection of the natural environment [6]. The Makhadzi is usually a position held by one of the Khosi's sisters, but only one sister can be chosen by the royal council who serves as an advisor to the Khosi, resolves conflicts within the royal family and participates in ritual ceremonies and rites of passage [19]. The traditional religion of the Vhavenda is based on the belief of a supreme being named Nwali who influences the world of the living by identifying his presence in storms, rains and earthquakes and is appeased through ritual ceremonies [19]. The Vhavenda believe that the deceased are taken by the ancestors, who continue to exert control over the lives of the living by bringing peace or ill fortune and are venerated and appeased through ritual practices [6, 19]. The Makhadzi and traditional healers serve to maintain a link between the dead and the living and are responsible for different rituals involving libations and prayers in veneration of ancestor spirits. Although these rituals may serve as a family affair, the Makhadzi of the royal family often serves as a representative for the whole of the royal ancestors and will perform public ceremonies such as the first fruits and vegetable ceremonies [19].

\section{Study site}

The study took place in six villages (Duthuni, Tshidzivhe, Vuvha, Lwamondo, Mashau and Tshiendeulu) located in the Vhembe District of the Limpopo Province, South Africa, and forms part of the eastern Soutpansberg Mountain Range in the Vhembe Biosphere Reserve (Fig. 1). The villages of Duthuni, Tshidzivhe and Lwamondo are located in the Thulamela Municipality and Vuvha, Tshiendeulu and Mashau in the Makhado Municipality (Fig. 1).

The area is characterised by a subtropical climate with moist winters and wet, warm summers [24]. The area experiences an annual rainfall of $500 \mathrm{~mm}$ of which $87 \%$ of rainfall occurs between October and March [24]. Annual temperatures range from $10{ }^{\circ} \mathrm{C}$ in winter to a maximum of $40{ }^{\circ} \mathrm{C}$ in the summer [24]. The Soutpansberg Mountain Range is a centre for botanical endemism in southern Africa and falls under the mountain bushveld vegetation unit of the Savannah biome that includes dense deciduous woodlands and evergreen montane forests and open savannah in places [25]. The southern slopes of the eastern portion of the Soutpansberg Mountain support dense deciduous woodlands at lower altitudes consisting of small-tree species (dominated by Diospyros whyteana (Hiern) P. White, Englerophytum magalismontanum (Sond.) T. D. Penn, and Schefflera umbellifera (Sond.) Baill) and dense evergreen montane forests consisting of small-tree species (e.g. Brachylaena transvaalensis Hutch. ex E. Phillips \& Schweick, Celtis africana Burm. f, Cussonia spicata Thunb) $[25,26]$. The more arid northern ridges consist of tall-trees (e.g. Acacia nigrescens Oliv, Adansonia digitata L, Brachystegia spiciformis Benth) and small-tree species (e.g. Combretum apiculatum Sond, Commiphora glandulosa Schinz) [26, 27]. Venda's landscapes have also undergone significant land-use change through the establishment of commercial forestry and tea plantations during the 1930s-1970s to provide economic development in the Venda homeland. The confinements of the former Venda homeland in the semi-urbanised villages surrounding the town of Thohoyandou necessitate a demand for housing, and clearing of land for agriculture has resulted in the degradation and fragmentation of montane forests and deciduous woodlands that are largely confined to river valleys and higher elevations of the mountain on south-facing slopes [27].

\section{Data collection}

Data was collected from September-November 2016 by working in collaboration with the community-based organisation Dzomo La Mupo who acted as a key gatekeeper to 


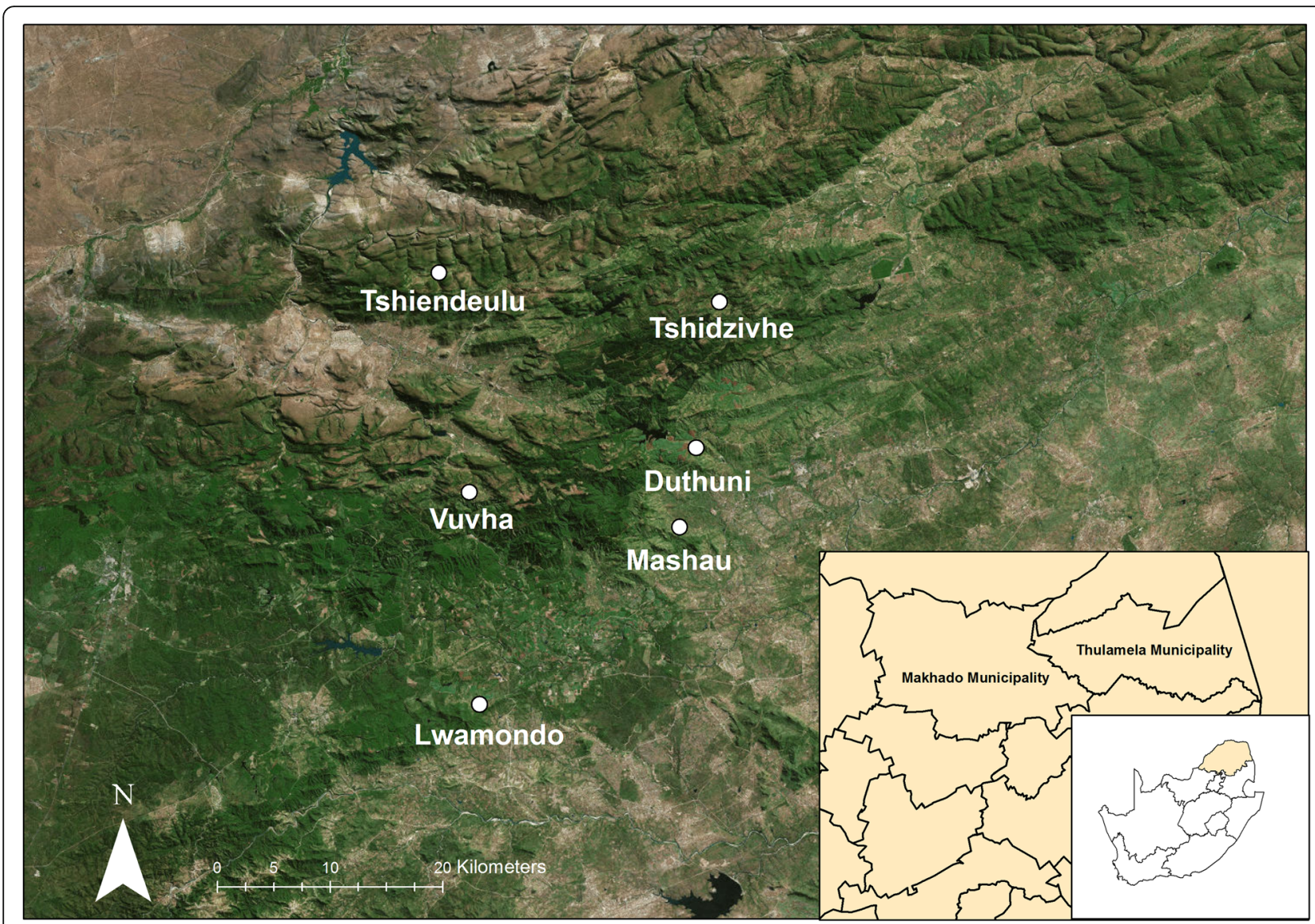

Fig. 1 Map of sampled villages of the Vhavenda community, Limpopo Province, South Africa

access the targeted villages. Initial meetings with communities were established in consultation with the Chief (Khosi) or headman (Mukoma) to describe the aims and objectives of the study, identify informants who were knowledgeable of plants and seek permission for the study. Each participant was presented with an information sheet and consent form (approved by the Research Ethics Committee of Cardiff University) which clarified the objectives of the study, and all informants were asked to sign consent forms to secure informed consent to participate in the study. Semi-structured interviews were conducted in the local language (Tshivenda) through the assistance of a translator and later translated into English. Questions focused on the important plant uses including their local names, habits of the plant, parts used, collection sites and plant uses. Local practices and belief systems associated with the management and protection of plant resources were explored. Finally, discussions with all informants addressed perceptions of how plant-based knowledge is transmitted and the perceived barriers for knowledge transmission. Selection of study participants was made using a snowball sampling strategy in consultation with the Khosi or Mukoma from each village to identify individuals for interview based on the condition that they were knowledgeable of plants or were specialists in the community, for example, traditional healers. A total of 31 people were interviewed, namely 18 females (58.0\%) and 13 men (42.0\%), ranging in age from 34 years to 85 years. Of all informants, $35.5 \%$ received no formal education, $29.0 \%$ received a primary school education, while $35.5 \%$ received a secondary school education.

\section{Plant collections}

Collections of plant specimens were obtained by walking in home gardens, cultivated fields, montane forests and deciduous woodlands. During collection, the species was classified according to its habit: tree, shrub, herbaceous, climbing or grass [28]. Plants were later classified according to their biogeographical region to determine whether they were native or exotic plants. The plant species were identified by PT with the aid of the literature and comparison with herbarium species, and voucher specimens were prepared and deposited at the University of Venda Herbarium $(\mathrm{UVH})$ in South Africa. Plant species were categorised as 'invasive,' 'naturalised' and 'casual alien' classifications [29, 30] and by drawing on species records of alien plants using the Southern African Plant Invaders Atlas (SAPIA) [31]. 


\section{Data analysis}

Descriptive statistics such as frequencies and percentages were used in the analysis of the data. The Use Value Index (UVI) and the Relative Frequency Index (RFI) were calculated to determine the most important plant species sampled [32]. The UVI is a measure of the relative importance, measured as the number of different uses of each species: $\mathrm{UV}=\Sigma U i / N$. It is calculated by the total number of uses of a plant mentioned by a participant $(U)$ divided by the total number of participants in the study. The RFI is an index of the local importance of each species: $\mathrm{RFI}=\mathrm{FC} / N$ in which the $\mathrm{FC}$ is the number of participants that mention the use of a species divided by the total number of participants in the study.

\section{Results}

\section{Indigenous plants of the Vhavenda}

There are a total of 84 plant species in the sampled communities all of which were identified to species level from 44 families (Table 1). The best represented families were Fabaceae with ten species and Apoynaceae, Asteraceae, Combretaceae, Cucurbitaceae and Rubiaceae all with a total of four species. The other families (64.3\%) were represented by one to three species.

\section{Species origin, status and habitat}

The majority of plants were native species $(73.8 \%)$ compared to exotics $(26.2 \%)$. The average year of settlement in the region was 60.5 years suggesting a considerable period of knowledge assimilation and experimentation with the local flora. The habits of the species were trees (53.2\%), herbs $(21.3 \%)$, shrubs $(8.5 \%)$, climbers $(5.3 \%)$ and grasses (1.0\%). The communities of Tshidzivhe, Vuvha, Lwamondo and Tshiendeulu were surrounded by small patches of montane forests and deciduous woodlands in river valleys and higher elevation slopes. Plant samples were collected for identification from home gardens $(89.7 \%)$, cultivating fields $(6.9 \%)$ and montane forests and deciduous woodlands (3.4\%).

The majority of plant species used were wild (54.8\%) compared to cultivated species $(20.2 \%)$ whilst $25 \%$ were both harvested in the wild and cultivated. When the plants were separated by habit, native species were mainly trees, and exotic species were mainly a combination of herbs and trees (Fig. 2).

Considering only the exotic cultivated species (Fig. 3), these were mainly trees and herbs that have originated from areas of Europe, North and Central America, Asia, Australasia and Tropical Africa before their introduction to South Africa (Table 1). Of the exotic tree species, Carica papaya L, Citrus limon (L.) Burm. F and Persea americana Mill were reported as naturalised or casuals in South Africa (Table 1).
Of the exotic cultivated herb species documented, Psidium guajava $\mathrm{L}$ and Ricinus communis $\mathrm{L}$ were listed as invasive. Exotic wild species were mainly herbs (Fig. 3) that were of European, North or Central America, North African and Asian origin. Of the exotic herbs species listed, Amaranthus hybridus L, Bidens pilosa L, Chenopodium album L, Colocasia esculenta (L.) Schott, Hibiscus trionum L, Obetia tenax Friis and Sonchus oleraceus (L.) L were reported as naturalised or casuals in South Africa (Table 1).

Native cultivated species were mainly trees (Fig. 3) to name a few included Celtis africana, Combretum erythrophyllum (Burch.) Sond, Faidherbia albida (Delile) A. Chev, Faurea saligna Harv, Philenoptera violacea (Klotzsch) Schrire and Rauvolfia caffra Sond. The Vhavenda continue to exploit native wild species mainly trees (Fig. 3), for example, Afrocanthium mundianum (Cham. \& Schltdl.) Lantz, Annona senegalensis Pers, Carissa edulis (Forssk.) Vahl, Cephalanthus natalensis Oliv, Combretum collinum Fresen, Diospyros lycioides Desf, Englerophytum magalismontanum and Ekebergia capensis Sparrm.

\section{Species use and frequency}

To our knowledge, six of the species documented have not been recorded in the ethnobotanical literature of local plants used by the Vhavenda, prior to this study (Table 1). Three of these species are exotic including Litchi chinensis, Macadamia ternifolia and Persea Americana, and other species include the exotic Athyrium filix-femina (L.) Roth and the indigenous Croton sylvaticus Hochst and Ziziphus rivularis Codd. The local uses for these species appear to remain unpublished, as similar Vhavenda ethnobotanical studies documenting the use of these plants could not be found in the literature. New Vhavenda traditional use records for 68 species were also identified as well as 14 partially new plant uses (i.e. variations on previously recorded uses) and presented in Table 1.

The species with the highest use value index were recorded for the Brachylaena discolor DC (0.23), Englerophytum magalismontanum (0.16) and Persea americana (0.19) representing the highest number of plant uses of all species documented (Fig. 4). The species with the highest relative frequency included Amaranthus hybridus (0.23) and Colocasia esculenta (0.23) as the most frequently cited species by informants (Fig. 4b).

Of the species identified, the majority were used for food (36.0\%), medicine $(26.1 \%)$, firewood $(11.8 \%)$, shade $(5.0 \%)$, cultural purposes $(5.0 \%)$, drink (4.3\%), domestic utensils (4.3\%), commercial use (2.5\%), charcoal (1.9\%), construction $(1.2 \%)$, crafts $(0.6 \%)$ and as indicator species for soil fertility $(0.6 \%)$. Of the 84 species identified, $61.7 \%$ were multi-use. Of all species identified, the leaves (25.7\%), fruits (20.8\%), wood $(16.0 \%)$, bark (13.9\%), roots $(9.7 \%)$, stem $(8.3 \%)$, seed $(2.8 \%)$, thorns $(0.7 \%)$, latex $(0.7 \%)$, flowers $(0.7 \%)$ and the whole plant $(0.7 \%)$ were used. 


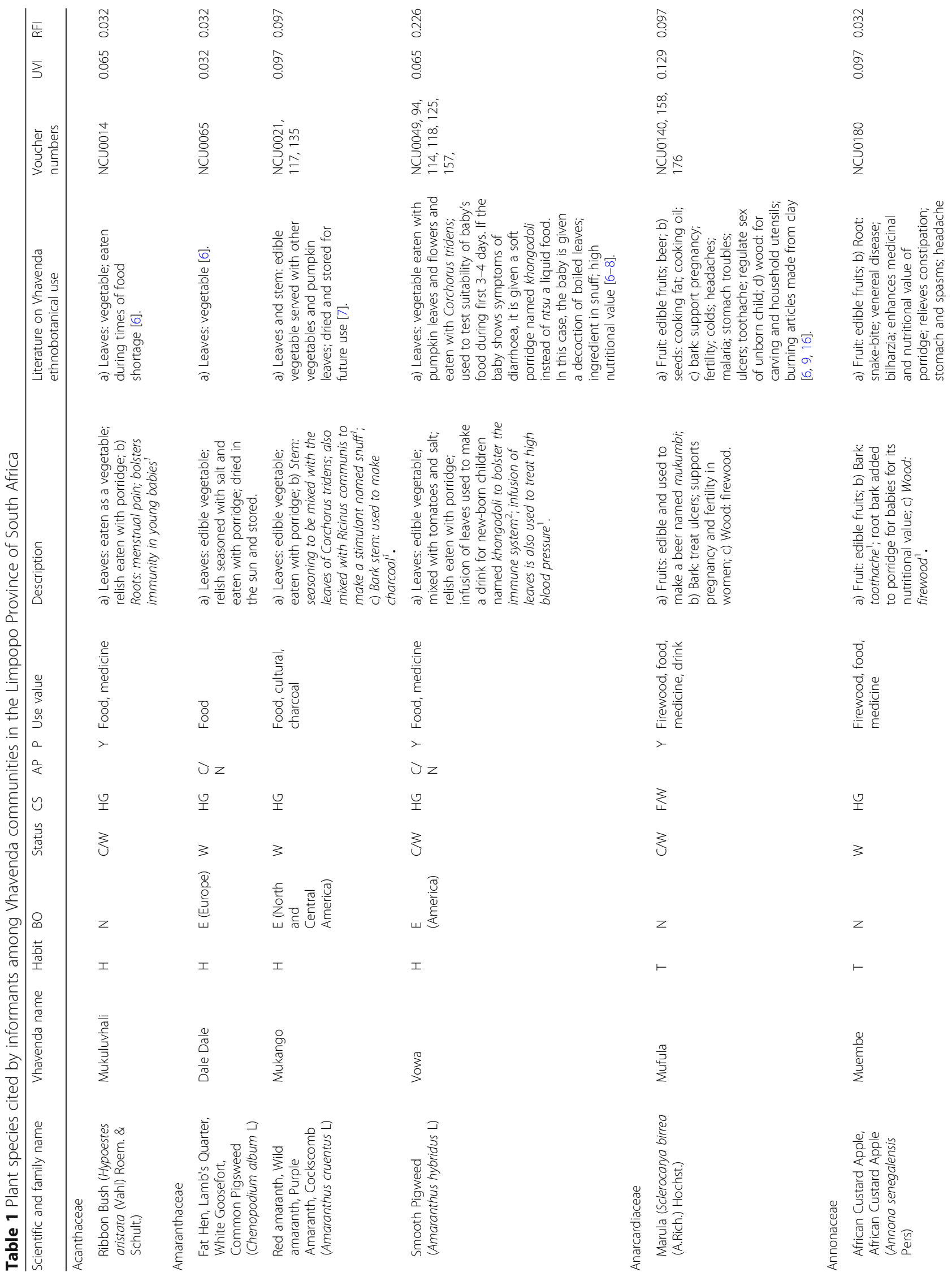




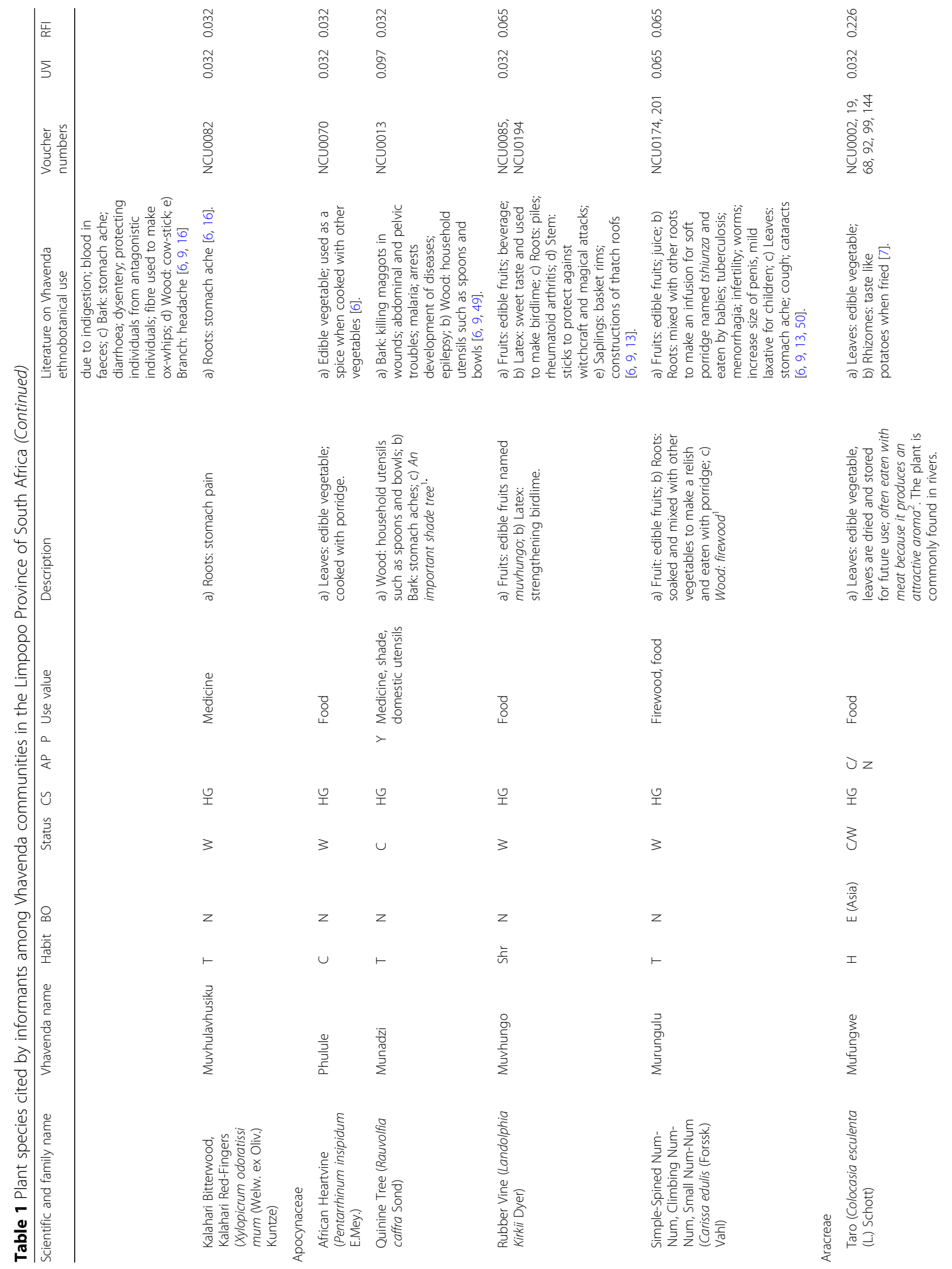




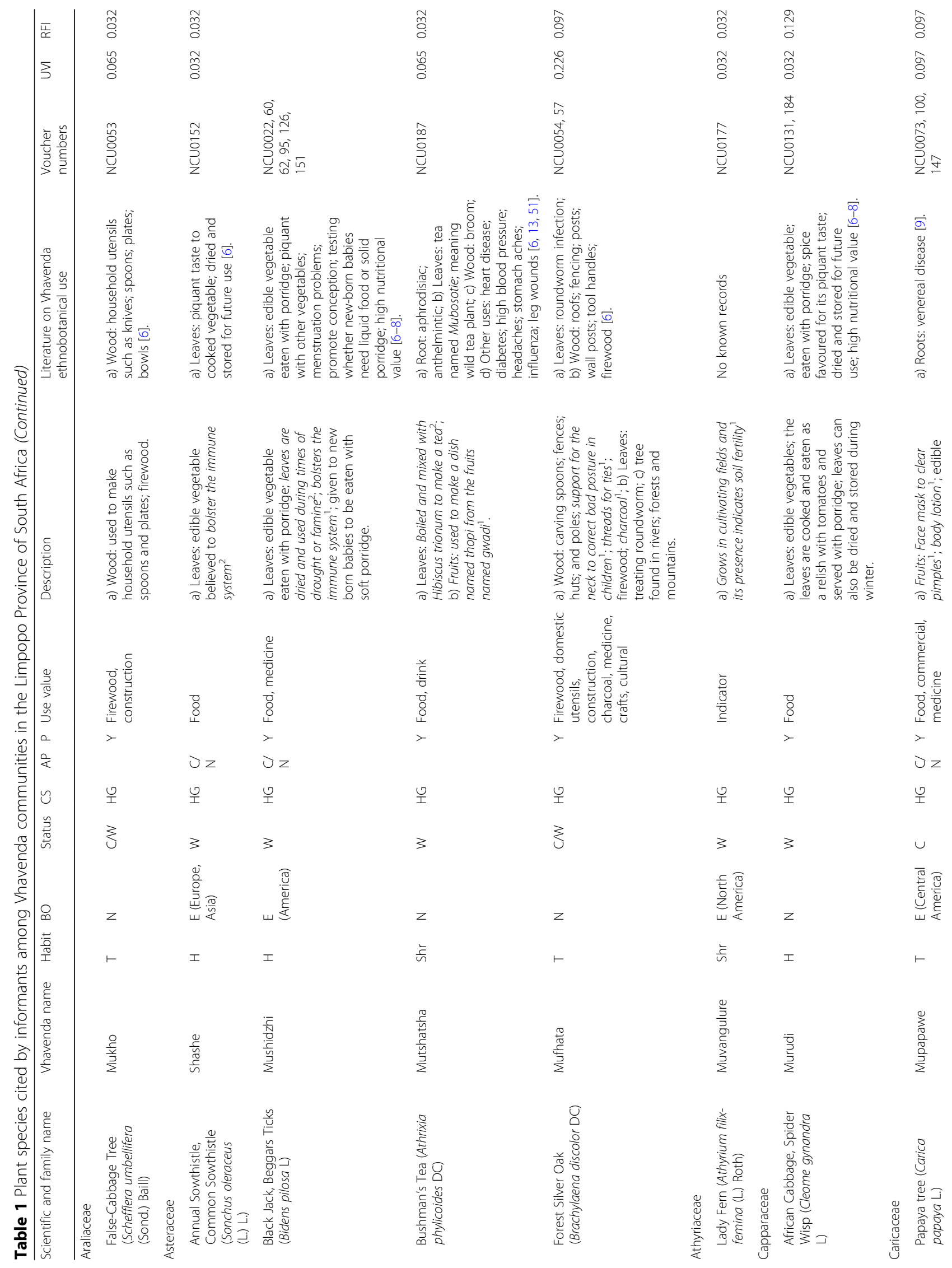




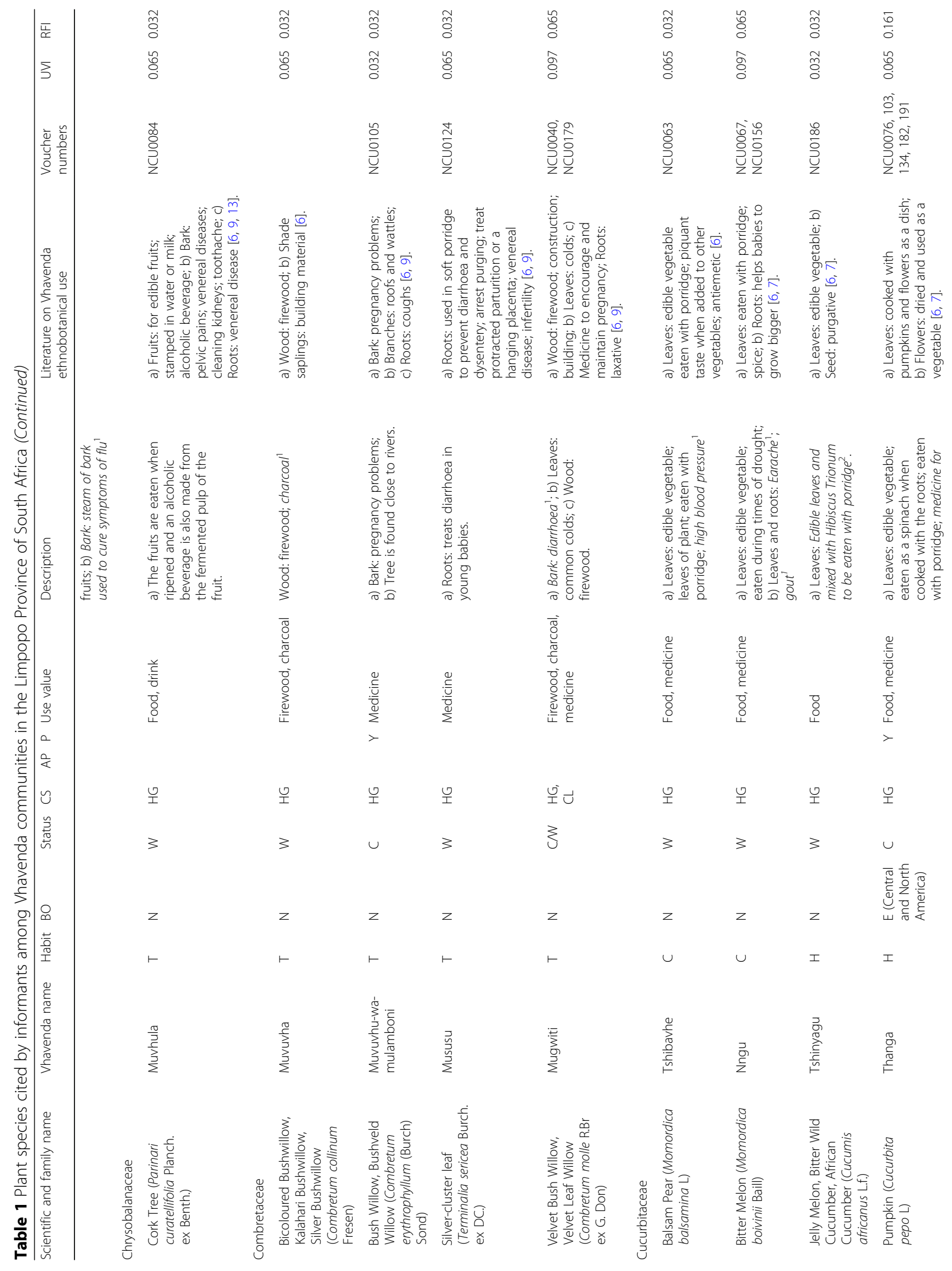




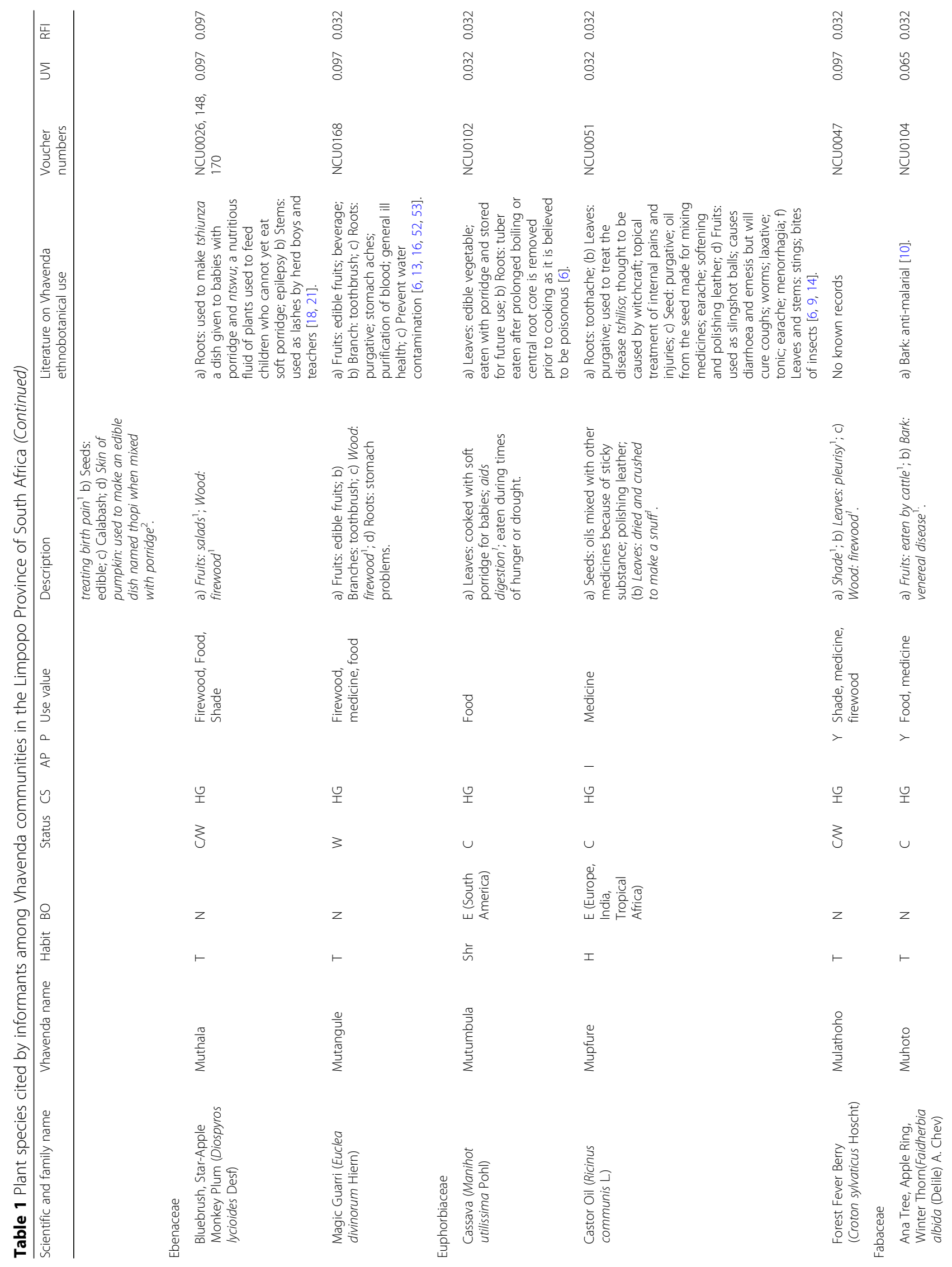




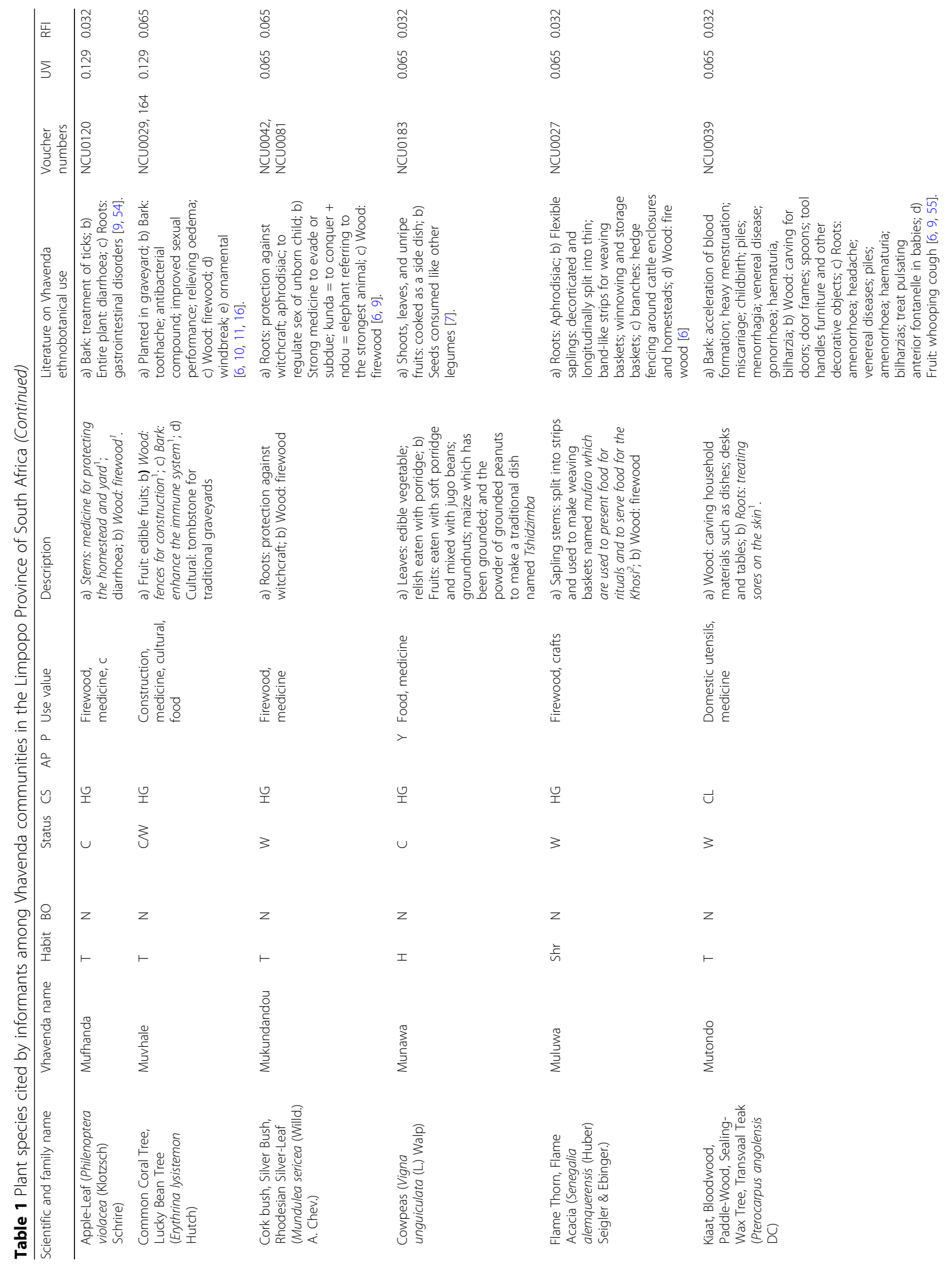




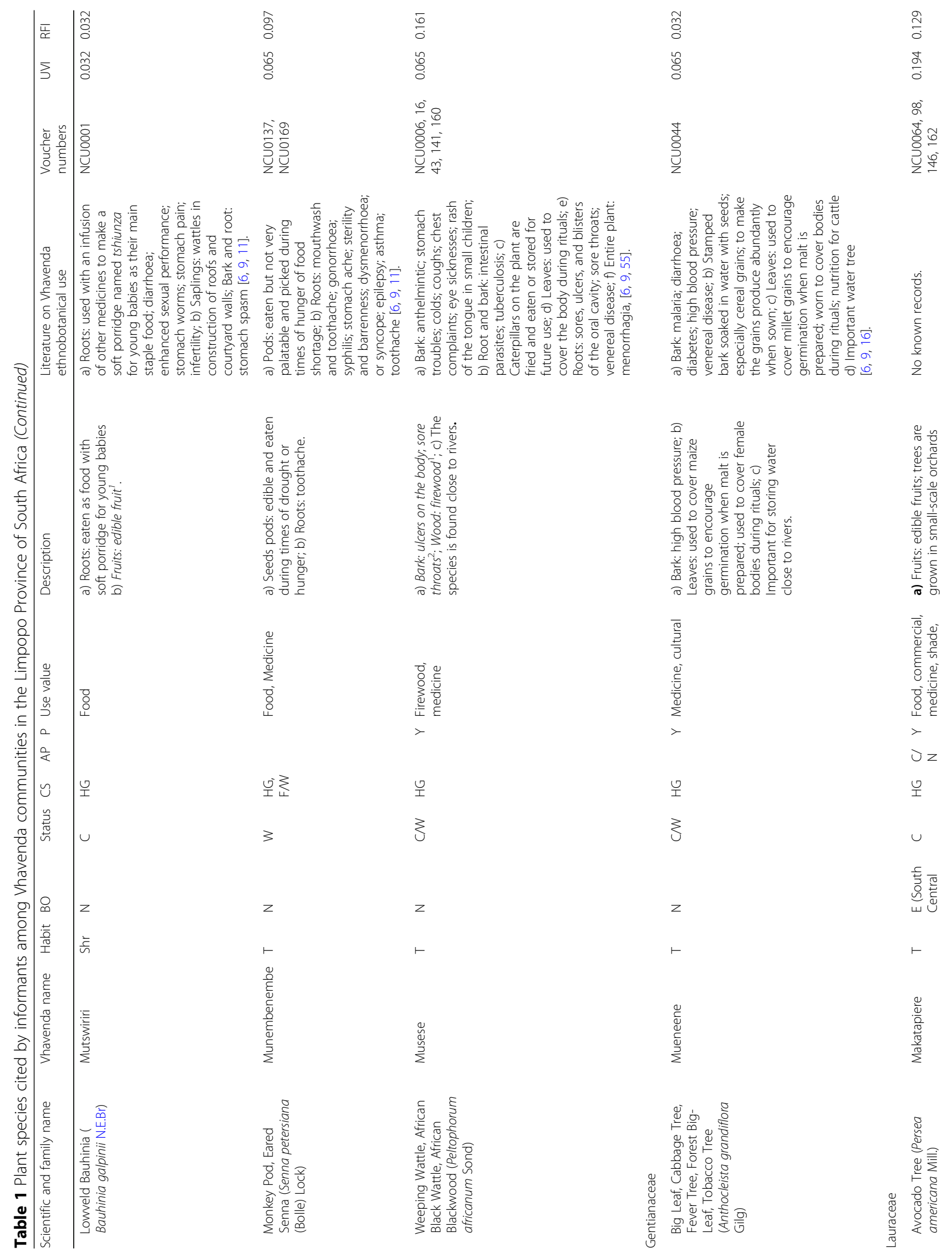




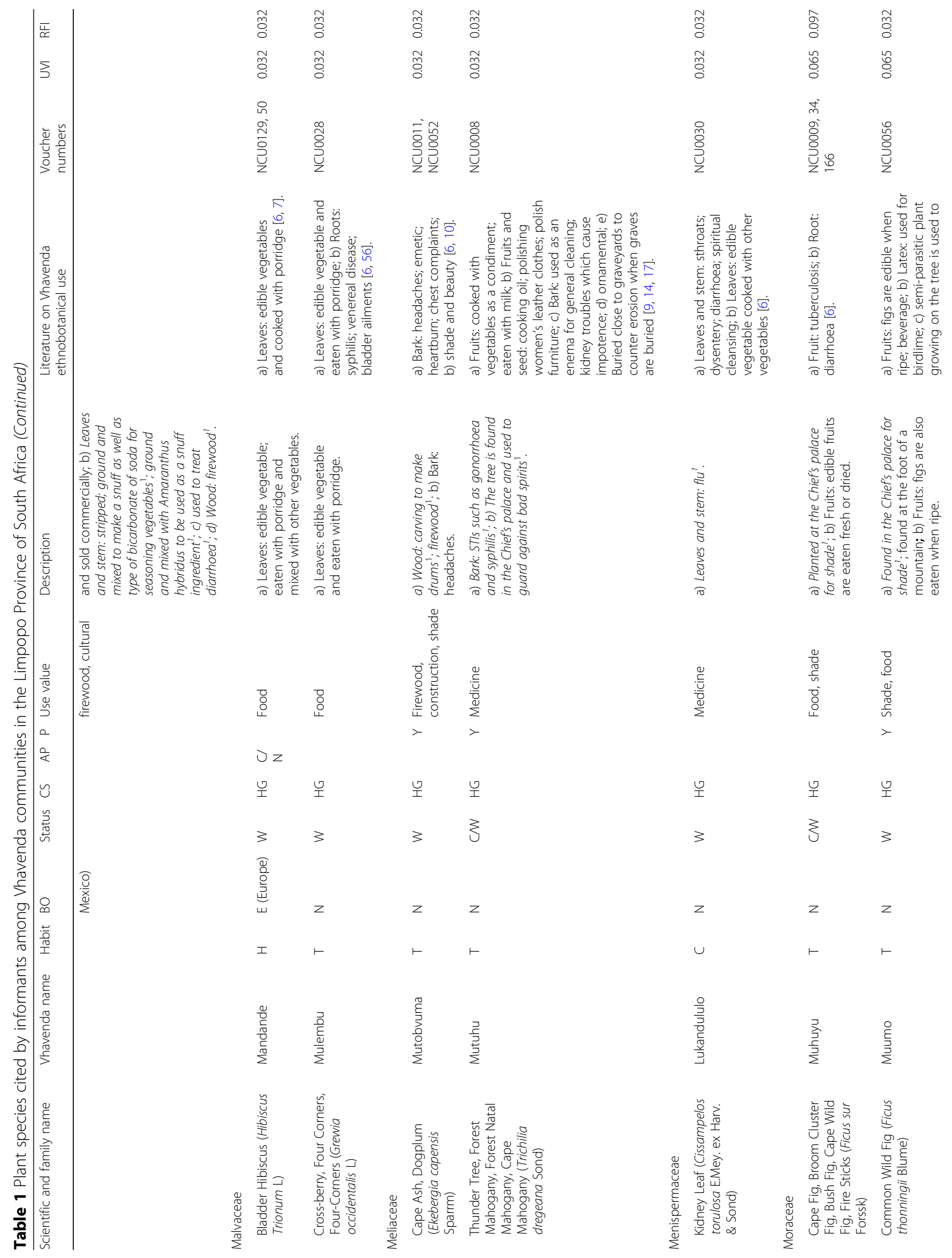




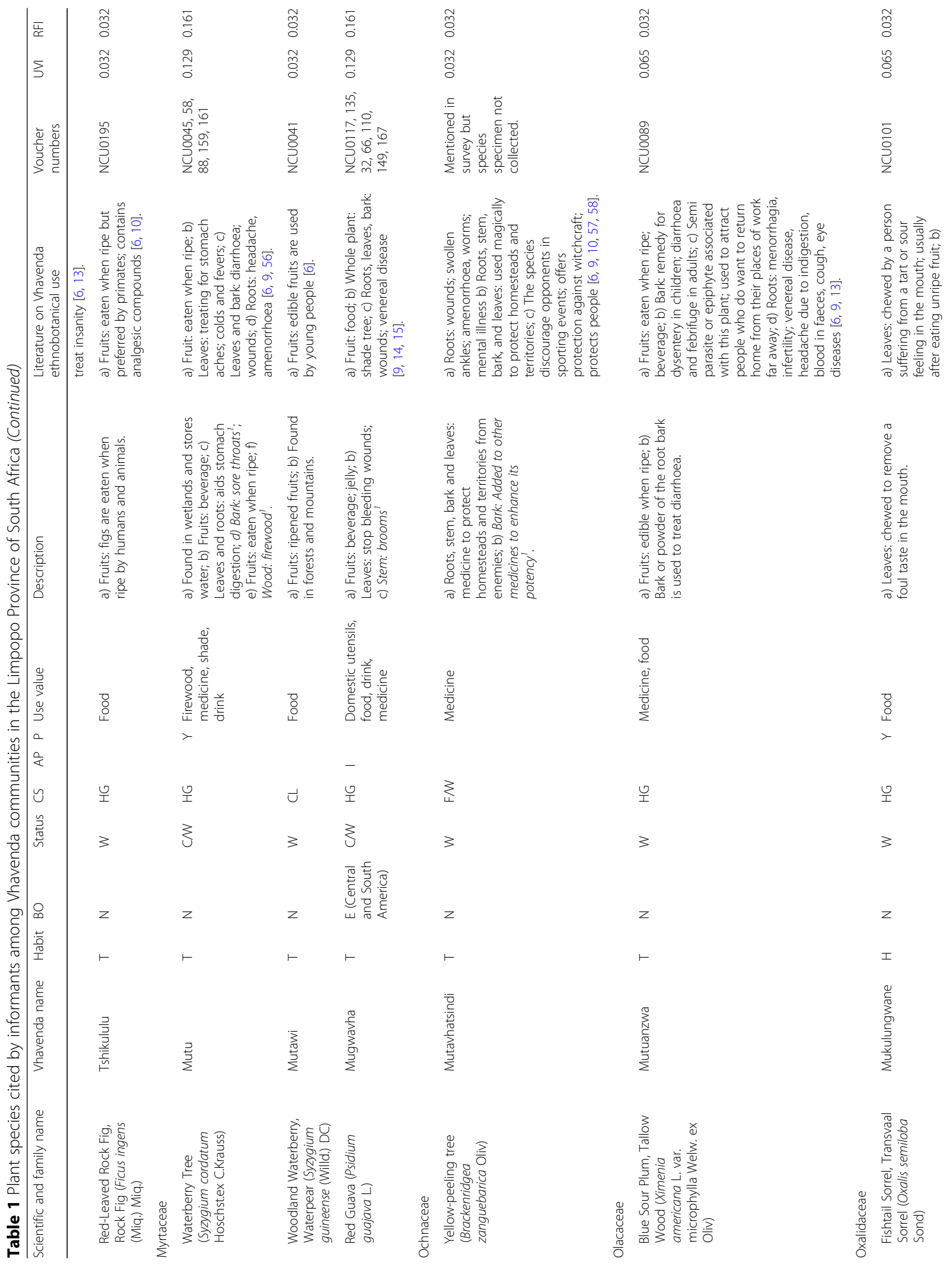




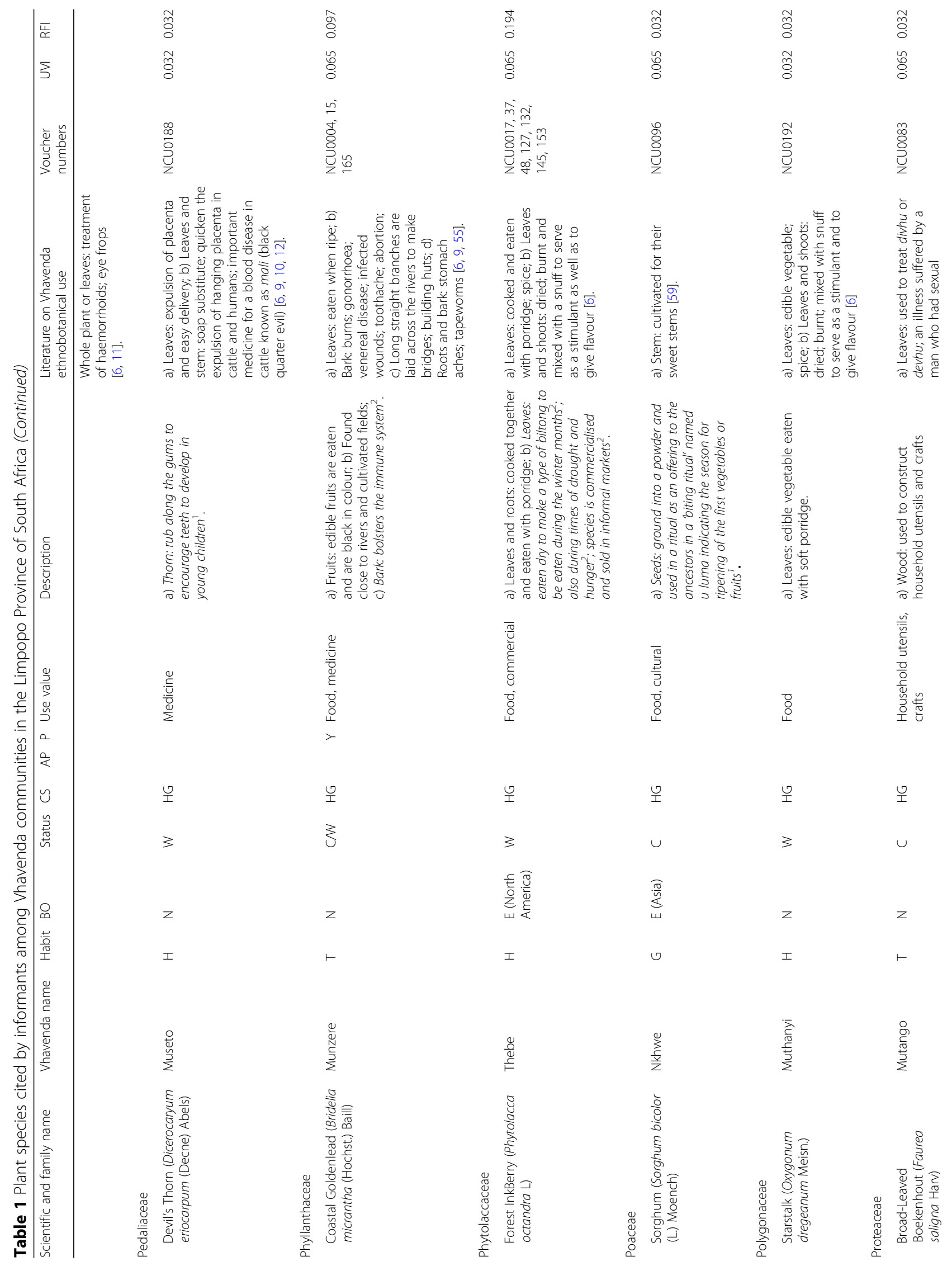




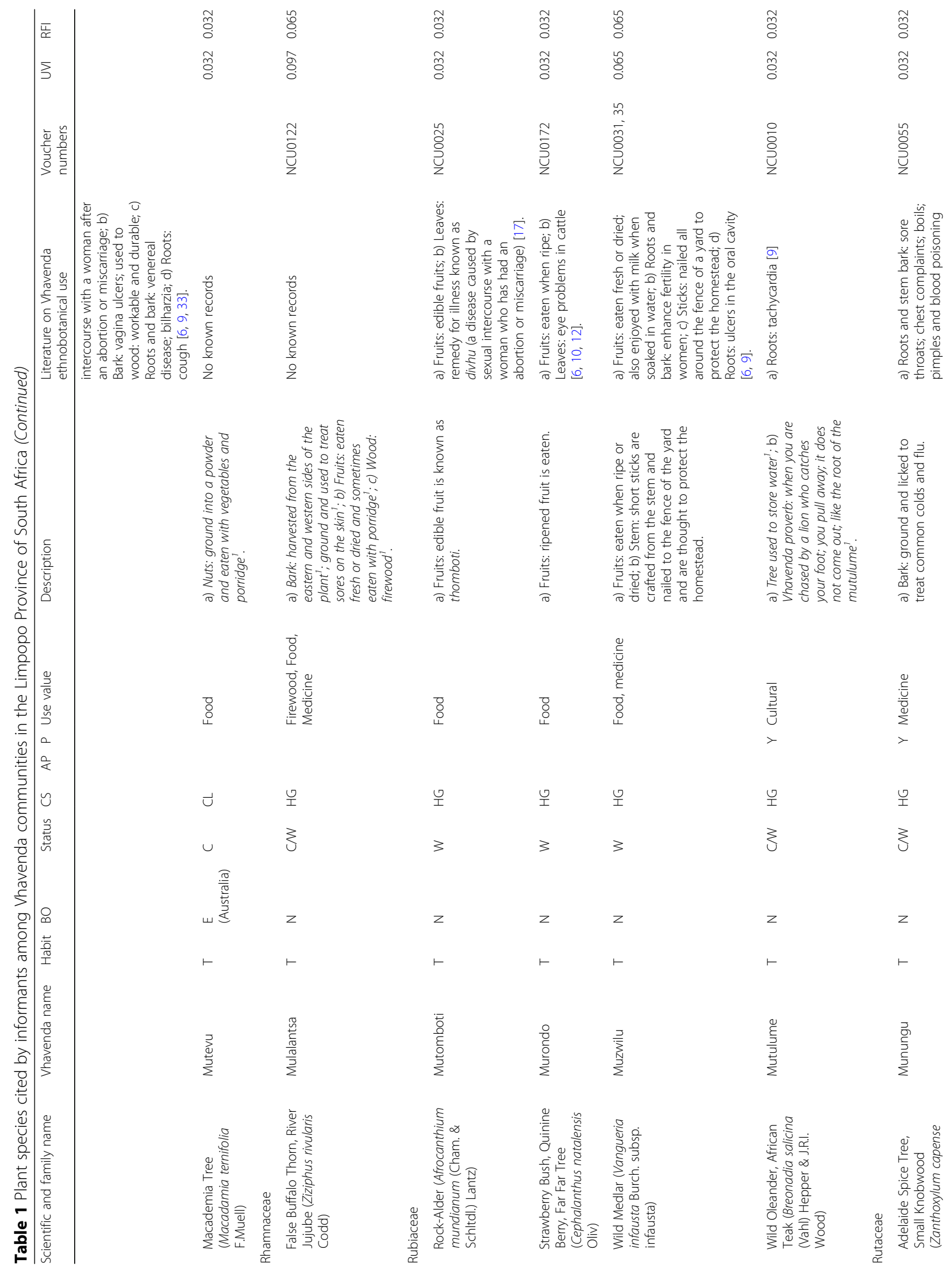




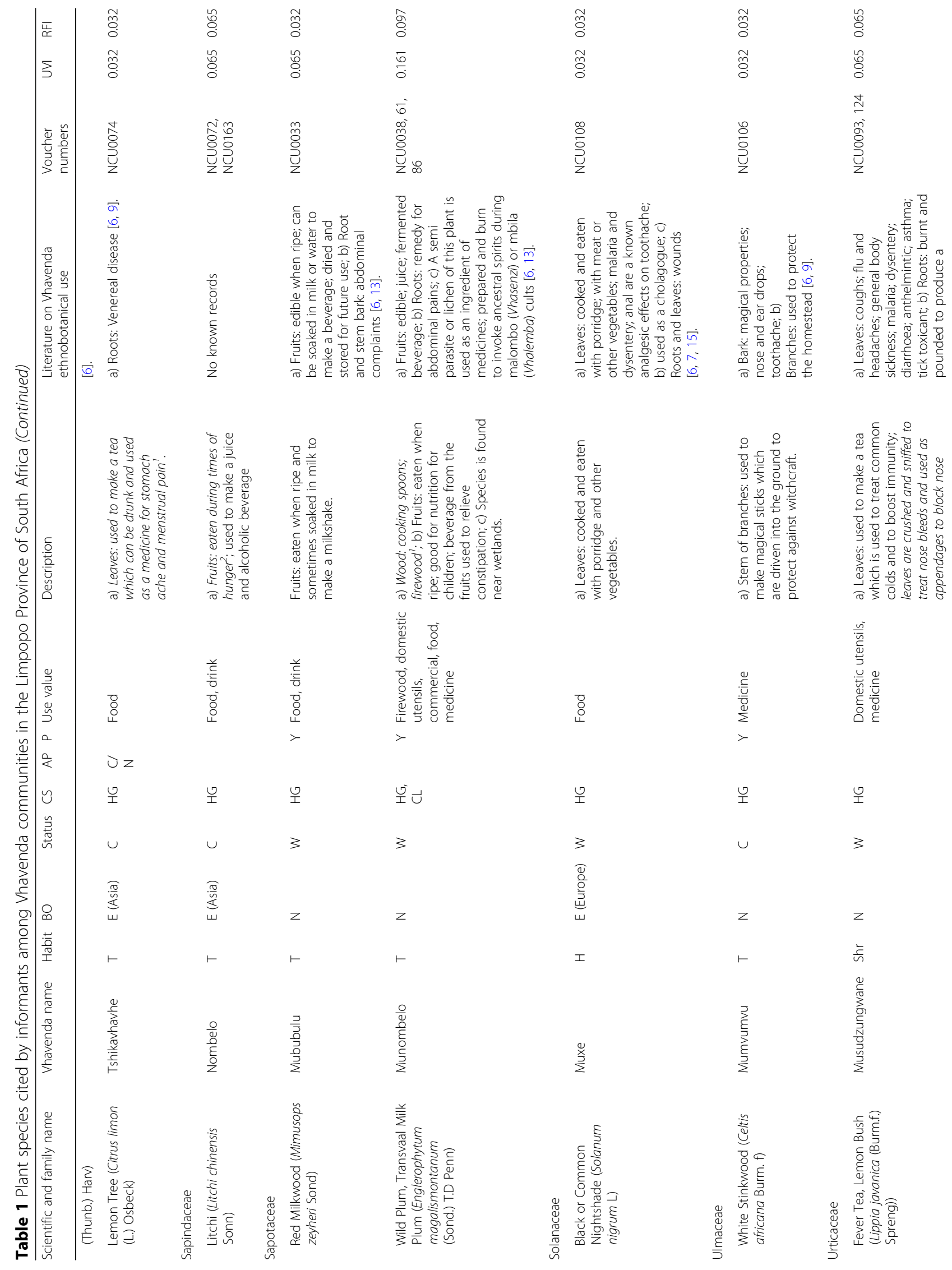




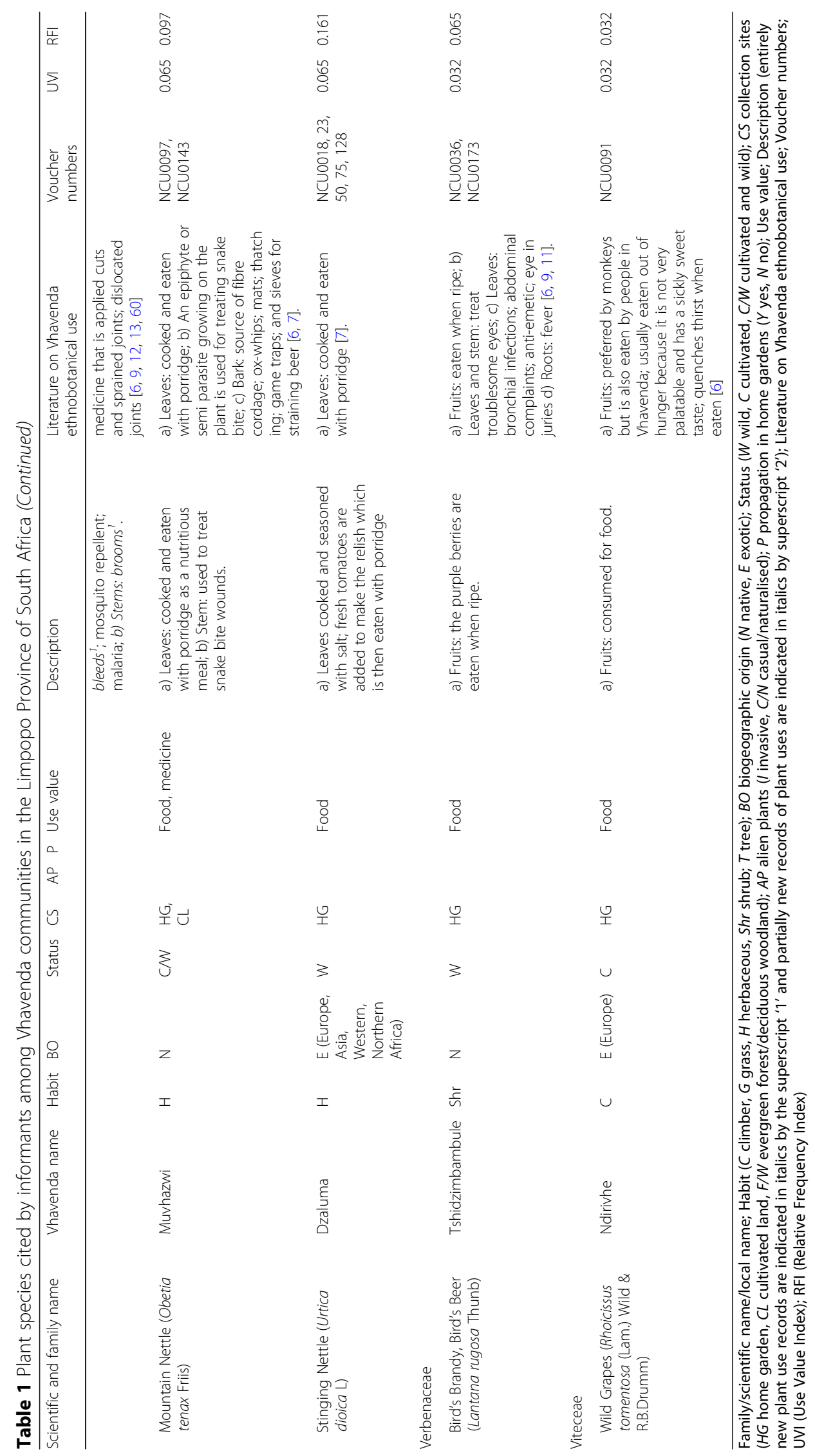



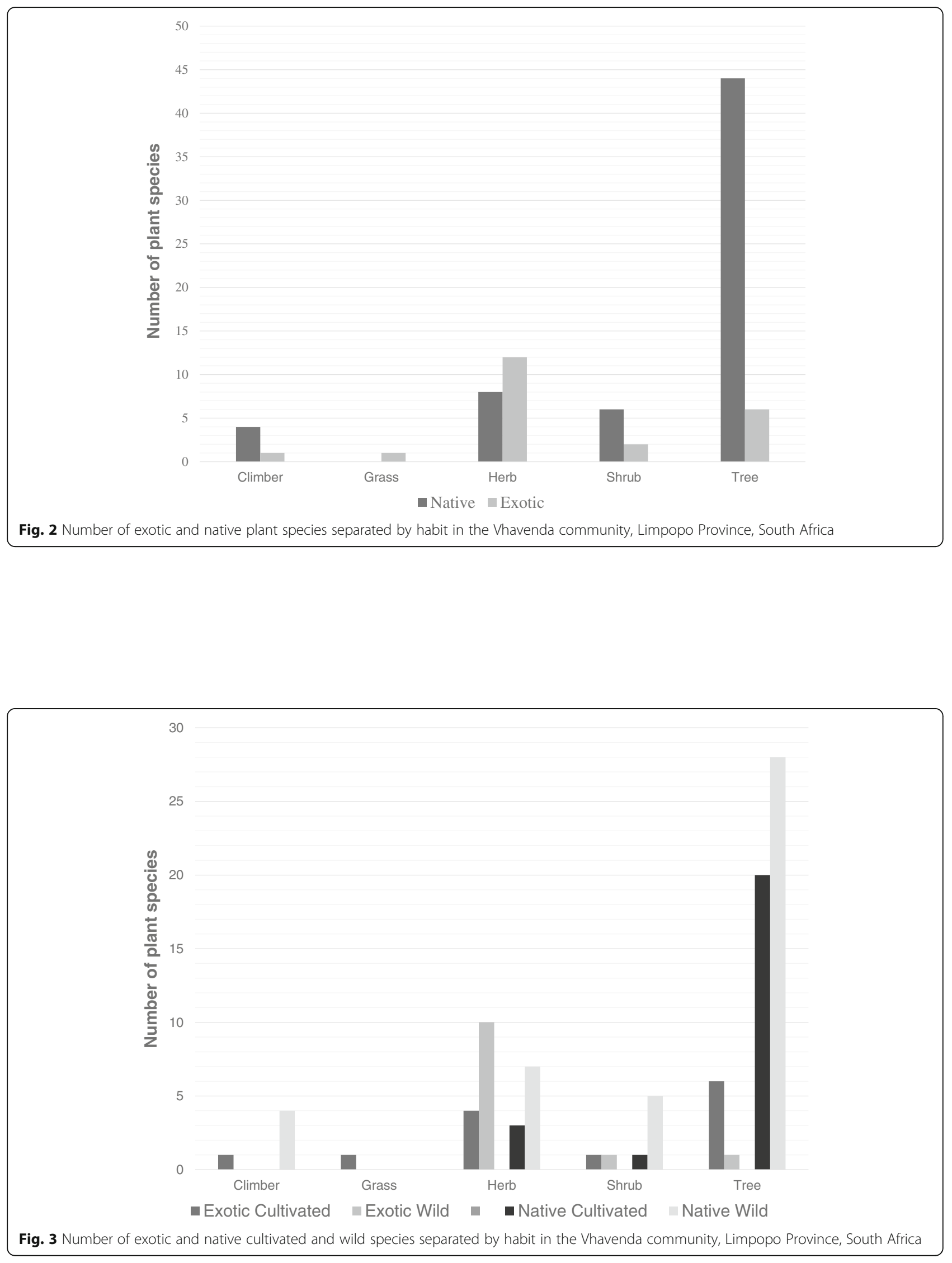


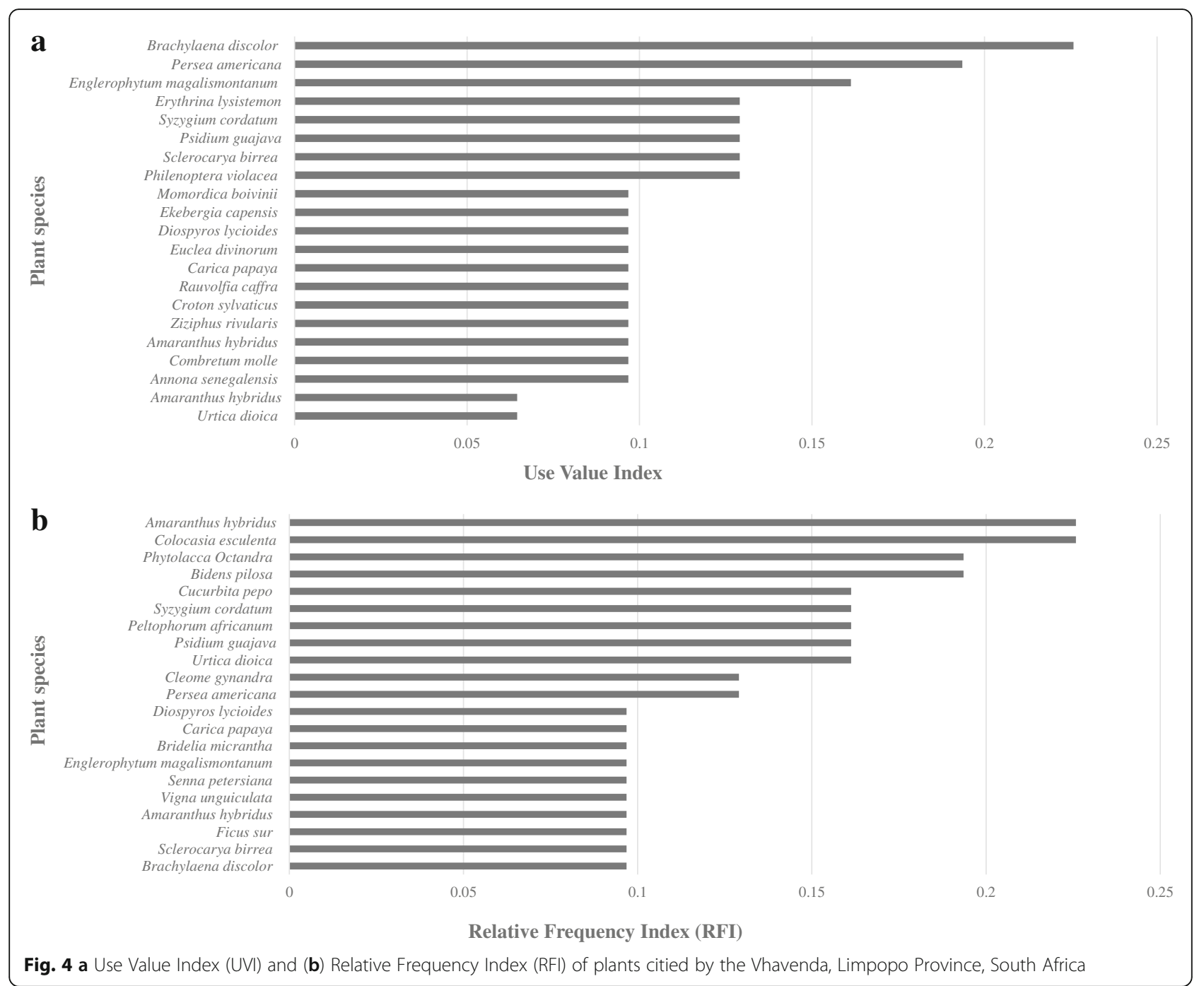

\section{Cultural practices associated with Vhavenda plants}

The Vhavenda integrate a range of strategies for protecting plant resources including prohibitions against certain plants from being used, the promotion of sustainable harvesting practices and the propagation of plant species to support ecological restoration (Table 2). The most common strategy for managing plant resources included taboos preventing trees from being cut down, used as firewood or taken back to the homestead for $11.9 \%$ of species. The following trees were prohibited from being cut down: Anthocleista grandiflora Gilg, Breonadia salicina (Vahl) Hepper \& J.R.I. Wood, Bridelia micrantha (Hochst.) Baill, Combretum molle R.Br. ex G.Don, Ekebergia capensis, Englerophytum magalismontanum, Ficus sur Forssk, Mundulea sericea (Willd.) A. Chev, Pterocarpus angolensis DC and Sclerocarya birrea (A.Rich.) Hochst. The tree Mundulea sericea is prohibited from being used as firewood in homesteads where cattle are present, and Celtis africana cannot be planted in the homestead. Sclerocarya birrea fruits can only be harvested when they have fallen to the ground; otherwise, the culprits were believed to experience a fever or snakes would appear in their homesteads. Brackenridgea zanguebarica Oliv is prohibited from entering Vhavenda homesteads, and a failure to adhere to the taboo results in sterility among household members. Brackenridgea zanguebarica is also prohibited from being used for firewood, hedge fencing, building work or wood carving.

The Vhavenda have developed selective harvesting practices, for example, plants are taken from specific areas and it is prohibited from returning to the same area in a year allowing the plants to recover. Only the tender leaves of Amaranthus hybridus, Cucurbita pepo, Momordica balsamina L, Momordica boivinii Baill and Phytolacca octandra L are selected allowing the leaves to reach maturity. Cucurbita pepo is only harvested after the flowering of the plant, indicating the time for harvesting when the vegetable has reached maturity. The leaves of Cucurbita pepo and Momordica boivinii 
Table 2 Traditional practices for managing plant resources in targeted villages

\begin{tabular}{|c|c|c|c|c|c|c|}
\hline Traditional practices & Duthuni & Tshidzivhe & Vuvha & Lwamondo & Mashau & Tshiendeulu \\
\hline Consultation of the Khosi or Mukoma to seek permission before harvesting plants & & $x$ & & $x$ & $x$ & $x$ \\
\hline Penalty for cutting down trees and the payment of a fine of ZAR 1000 (75USD) & & $x$ & & & & \\
\hline Stem bark is harvested on the eastern side of the plant & $x$ & & & & & $x$ \\
\hline Only the lateral roots of plants are collected & $x$ & & $x$ & $x$ & $x$ & $x$ \\
\hline Soil is covered back over harvested roots & $x$ & & & & & $x$ \\
\hline Propagation of plant species in home gardens & $x$ & $x$ & $x$ & & & \\
\hline $\begin{array}{l}\text { Taboos preventing trees from being cut down, used as firewood or } \\
\text { being placed in the homestead }\end{array}$ & $x$ & $x$ & $x$ & $x$ & $x$ & $x$ \\
\hline $\begin{array}{l}\text { Edible fruits from trees are only harvested when the fruits have fallen } \\
\text { to the ground or ripened }\end{array}$ & & $x$ & & & & $x$ \\
\hline Some species are only harvested for their tender leaves & & $x$ & & & & $x$ \\
\hline Only the deadwood if trees is collected for firewood & & & $x$ & $x$ & $x$ & \\
\hline Consultation with the ancestors before harvesting a plant & & & $x$ & & & \\
\hline Women are not allowed to collect plants during menstruation & & & $x$ & & & $x$ \\
\hline Plants harvested only from specific areas & & & & $x$ & $x$ & \\
\hline Prohibitions from harvesting plants from the same area each year & & & & $x$ & $x$ & \\
\hline $\begin{array}{l}\text { Some species are only planted and harvested during certain seasons } \\
\text { following ritual ceremonies by Makhadzi or traditional leaders. }\end{array}$ & & $x$ & & & & $x$ \\
\hline $\begin{array}{l}\text { Species only harvested when the flowers are present indicating the } \\
\text { maturity of the plant }\end{array}$ & & & & & & $x$ \\
\hline
\end{tabular}

Legend: $\mathrm{X}$ indicates the presence of traditional practices for managing plants in a village

must not be harvested or touched by menstruating women; otherwise, it is believed that the vegetable will shrink in size. The wood of Pterocarpus angolensis is often placed in home gardens to prevent menstruating women from entering the garden. Similar beliefs are also extended to the harvesting of fruits for Sclerocarya birrea where only elder women who have experienced menopause are permitted to harvest the fruits. The bark from trees such as Ziziphus rivularis is harvested from the eastern side of the tree, due to a belief that bark harvested from this side has the highest nutritional level of all sides and the wound is covered with a mixture of soil and water to aid the recovery of the tree. Many of the practices described traditional healers to harvest plants for medicines were conducted in a manner to prevent the destruction of an entire tree, for example, only the horizontal edges of tap roots were removed from each side of the plant and the remaining roots covered back over with soil.

Of the 84 plant species identified, $34.5 \%$ of the species seeds were stored and saved for propagation in home nurseries and were mainly native $(82.8 \%)$ compared to exotic (17.2\%) species (Table 1). This practice is motivated by the need for individuals to grow important herbs or trees for food or their medicinal value; however, groups of women were also observed developing nurseries in their home gardens for the restoration of indigenous montane forests close to sacred groves and river valleys.

\section{Cultural institutions associated with Vhavenda plants}

In the villages of Tshidzivhe, Lwamondo and Tshiendeulu, the Khosi and Mukoma continue to play an important role in monitoring compliance of rules to harvest indigenous plant species in an area under his jurisdiction and the reporting of unsustainable harvesting practices. The Khosi is also consulted by traditional healers prior to harvesting trips undertaken by those who desire firewood or medicines from the forest. Often, the Khosi or Mukoma uses this traditional system to monitor plant populations, and if overharvesting or ill behaviour is observed, individuals are called to the Khosi's palace and issued with a sanction in the form of a fine.

The agriculture cycle of the Vhavenda is imbued with a form of wisdom tied the contemporaneous life cycles of different species interlinked with knowledge of their environmental requirements and seasonality, social norms, taboos and ceremonies to indicate rules for knowing when to cultivate, plant and harvest. The timing of agriculture cycles for soil preparation, planting and cultivation are determined by dzima which refers to different seasons determined by the phases of the moon. The first dzima occurs in September (khubvumedzi) or October (tshimedzi) where the land is cleared, the soil is tilled and seeds are sown. Public rituals and ceremonies are integrated into the agricultural practices of the Vhavenda in the villages of Tshidzivhe and Tshiendeulu, for example, one informant described the ritual of $u$ suka referring to the mixing 
of seeds which were mixed with a medicine and sown into the perimeters of the field before the ploughing season to enhance soil fertility. Informants reported that seeds were also doctored before planting and rain-making rituals were conducted to enhance the crop yield.

In January (phando), the second dzima commences in summer (tshilimo) where vegetables and crops are harvested, and a second round of planting commences. Other rituals were performed to give thanks to the ancestors after the harvest, for example, January was often indicative of the ripening of wild fruits and vegetables which were consumed after the first fruit rituals named $\mathrm{u}$ tungula or $u$ lumisa were performed as thanks to the ancestral spirits. When the crops are ready for harvesting, the Makhadzi picks a sample of each vegetable or fruit that are cooked with herbs. She performs a ritual where a libation of unfermented beer is poured into clay pots as an offering to ancestral spirits and to inform that cultivation is ready; this is named $u$ luma the biting of the first fruit. The fruits of the Marula Tree (Sclerocarya birrea) are often harvested during this time when the fruits have fallen to the ground indicating the time for harvesting. A third dzima commences from May (shundunthule) onwards during the winter period (mavhuyahaya) where the second round of crops are harvested, and a rest period takes place until September where the fields are left fallow and domestic livestock graze on the remains of the harvested crops. Traditionally, this period was also marked by ritual ceremony in July named thevhula a form of thanks giving to share the final harvests with the ancestral spirits.

\section{Knowledge acquisition and barriers for knowledge transmission}

Plant knowledge and management practices were reported to be transmitted from relatives (grandparents and parents) (48.4\%), self-taught through time spent planting and harvesting plants on the land (19.4\%), through apprenticeships with traditional healers $(16.1 \%)$, initiation schools (9.7\%) and clan gatherings (6.4\%). Acquired plant knowledge from everyday interactions was taught through relatives by spending time accompanying family on plant harvesting trips, planting and collecting plants for food and during meal preparation. Some individuals also specified that songs and fables were taught by family members to illustrate of forms of appropriate conduct and were often imbued with lessons in ecology and proper ways of respecting one another. Others taught themselves how to identify plants through time spent planting and harvesting or sought the guidance of more knowledgeable individuals in the village. Traditional healers learnt about plant medicines through apprenticeships with more experienced healers. Formalised cultural institutions such as initiation schools where girls and boys learn about the laws of life, the environment, sexuality, gender responsibilities and respect for the elderly also play a role in transmitting plant-based knowledge. Others claimed plant knowledge was learnt during clan gatherings and ritual ceremonies. Interviews with elders identified that taboos and belief systems were considered important for encouraging individuals and communities to follow traditional customs and laws, for example, clan gatherings would occur at the Khosi's palace where individuals were reminded how to observe local taboos, rituals and practices. In turn, traditional leaders play a prominent role in reviving rituals to set an example for others during communal celebrations and to act as role models for the rest of the community.

Interviews with elders revealed a disjuncture between knowledge exchange between elders and youth and a loosening of more formalised learning platforms for knowledge sharing about plants, taboos and social norms. Initiation schools, clan gatherings and communal ceremonies such as the vegetable and first fruits ceremonies are infrequent and only observed in villages that are isolated and maintain their traditions. The interchanges between knowledge holders, the place where knowledge is shared and the novice who is able and willing to experience such memories are few. There are fewer skilled experts 'on the land' by local people spending more time in the classroom at school or university, in the town centre, or conducting business away from home. Traditional leadership roles of the Khosi and Mukoma have changed with traditional leaders spending less time in their communities and fewer clan gatherings being held in villages resulting in partial knowledge of village affairs and issues on the ground. Traditional healers may no longer consult with the Khosi before harvesting and firewood trips. This is observable where people collect plant material in the absence of members of the tribal authority and do not observe the taboos and traditional cultural practices.

Observations by interviewees identified how cultural practices and beliefs are re-evaluated internally by young generations. As education becomes a primary facet of growing up in Venda, school and university education has devalued cultural institutions and traditional systems of authority over land and natural resources. New roles exist in the community for youth who have returned to their homes from university to exercise household decision-making power and challenge the authority and traditions of their elders. The emergence of new ideals among youth and adults associated with acquiring wealth and status has led to a form of economic stratification and lessening of communal traditional values and responsibilities. Informants stated that Christianity was originally initiated through mission education, and their teachings have influenced perceptions of practices and beliefs associated with ancestral spirits. The main 
observable impact is the demeaning of local cultural practices, beliefs surrounding taboos and rituals associated with ancestor veneration challenging the medicinal, magical and religious aspects of Vhavenda life.

\section{Discussion}

\section{Characterisation of documented plant species}

Fabaceae represented the most important plant family with the highest diversity of plant species recorded among the Vhavenda. Similar studies in the region have highlighted Fabaceae as the most important family for medicinal plants $[10,11,33]$ and the treatment of livestock diseases [12] whilst others have reported the importance of the Apocynaceae for the use of plants for traditional beverage-making plants [13]. The result is unsurprisingly considering Fabaceae represents the third largest family of angiosperm plants with over 20,856 species documented worldwide [34]. The most frequently recorded plant species found in this study are trees followed by herbs, which is similar to other ethnobotanical studies on the Vhavenda [12, 13, 33]. Trees and herbs have also been recorded as the most dominant life forms used by other cultural groups such as the Bapedi in the Limpopo Province [14]. The preference for trees and herbs among the Vhavenda may reflect the ease of collecting herbs both in the wild, through their cultivation in home gardens and the all-season availability of trees, providing a continuous supply of ecosystem services for local people [35]. The Vhavenda possess a long-term accumulation of learnt knowledge of the use values of biologically diverse indigenous plant species as evidenced through the dominance of mainly native species $(73.8 \%)$. There were preferred places for plant gatherings although many of the collected species used for vouchering were mainly identified in home gardens and cultivated lands. Although the majority of informants continue to harvest wild plant species from forests and woodlands, the relatively low frequency of these species for vouchering may also relate to the declining presence of forest and woodland cover in the region due to the establishment of pine and eucalyptus plantations and residential housing expansions [36]. Many species documented in this study were wild (54.8\%) compared to cultivated species (20.2\%). In the Vhembe District, other researchers also documented a dominance of wild plant species used by the Vhavenda because the properties of wild plants are perceived to be more potent compared to cultivated species for medicinal purposes [12]. It is also important to note that some individuals also gathered wild plants along trails between residential areas, cultivated lands, forests and woodlands. Other studies have shown a change in the collection of plants in communal lands to collecting species associated with disturbed sites located closer and within residential areas
$[37,38]$. The presence of both wild successional and cultivated species highlights the elevated importance of disturbance regimes for plant utilisation and management.

The Vhavenda use a relatively lower number of exotic plants $(26.2 \%)$ but have managed to domesticate and cultivate a range of exotic trees in home gardens and small-scale orchards, for example, Macademia ternifolia and Persea americana are in demand within local markets, and as a means of improving yields and incomes for rural farmers. Carica papaya, Citrus limon, Litchi chinensis and Psidium guajava are favoured as domestic fruit trees. Exotic cultivated herbs such as Amaranthus hybridus, Colocasia esculenta and Cucurbita pepo are often consumed as vegetables and have become a vital component of the local diet and economy. Two invasive species used by the Vhavenda, Psidium guajava and Ricinus communis, have also been documented by other researchers as part of Venda's repository of useful plants $[14,15]$. Despite the relatively low utilisation of exotic and invasive species, their use is also indicative of the positive role of widely dispersed species in the process of ethnobotanical adaptation as new species become introduced over time.

To our knowledge, new ethnobotanical literature for six new species not previously documented in the scientific literature are used by the Vhavenda including Athyrium filix-femina, Croton sylvaticus, Litchi chinensis, Macadamia ternifolia, Persea americana and Ziziphus rivularis. In addition, 68 new and 14 partially new uses of Vhavenda plants were also identified for a variety of species providing a more complete insight into the pattern of plant use in the Vhavenda ethnobotanical record. New documented species records and use values indicate that ethnobotanical knowledge of the Vhavenda is incomplete particularly regarding the utilisation of exotic species which is largely overlooked. Plant species are harvested not only for food and medicine but also for sources of firewood, shade, cultural and spiritual purposes, drink domestic utensils, commercial use, charcoal production, construction, crafts and as indicator species for understanding soil fertility. Other studies on the Vhavenda have highlighted similar uses although there has been an inherent bias towards studies of plants for food [7, 8], medicines [9-12] and other cultural and spiritual purposes $[16,17]$.

The native Brachylaena discolor was cited as having the highest number of uses for firewood, construction, crafts, domestic utensils, charcoal, medicine and its cultural use. The wood is favoured for carving spoons, fences, huts and poles as well as roofs, wall posts and tool handles [16]. The wood is also used to provide a support for the neck to correct bad posture in children and to make threads for ties. The leaves are used to make a medicine to treat roundworm [16]. Persea americana was cited as having the highest number of uses for food, medicine, shade, firewood and its commercial and 
cultural value. Persea americana are being increasingly cultivated by emerging farmers in community orchards to support local livelihoods. Although tropical fruit production is not traditionally part of Vhavenda culture currently, the Vhembe District represents the second largest district to produce mangoes, avocadoes, macadamia nuts and bananas with the Limpopo Province being the largest exporter of avocadoes in the country [24]. The species most frequently cited by informants included Amaranthus hybridus and Colocasia esculenta, both exotic to South Africa that have become naturalised in South Africa and are now favoured as vegetables and for their nutritional value. Amaranthus hybridus is thought to bolster the immune system and alleviate high blood pressure. The ethnobotanical records for these species demonstrate similar uses, for example, Amaranthus hybridus is a popular leafy vegetable, the leaves are eaten with pumpkin leaves and flowers and eaten with Corchorus tridens $\mathrm{L}$, the species is also used to test suitability of baby's type of food during first 3-4 days after birth. If the baby shows symptoms of diarrhoea, it is given a soft porridge named khongodoli instead of ntsu a liquid food [6-8]. Colocasia esculenta has previously been documented as a favoured leafy vegetable among the Vhavenda [7].

\section{Cultural practices and institutions for plant management and conservation}

The current study identifies a range of species-specific taboos associated with ten plant species to prevent them from being cut down, used as firewood and taken inside homesteads. These species are important as they are also favoured for their use as firewood, edible fruits, famine foods and medicines. Other studies have also documented similar taboos preventing the same trees from being cut down, for example, Anthocleista grandiflora 'maintained the status of the territory, Combretum molle is a favoured shade tree and Ekebergia capensis attracts rain [16]. Taboos among the Vhavenda have also been implemented to prohibit certain trees from being misused because of medicinal and magical beliefs associated with them. Sacred trees used to protect territories or homesteads named ' $u$ vhea mudi' are tabooed, for example, Philenoptera violacea is not used for firewood because of a belief that burning it inside the homestead can lead to the dissolution of marriage $[6,16]$. Some species have traditionally been used to protect against invasion by other tribes and against natural disasters. Similar species are also tabooed because they are used to protect families inside the homestead, for example, Celtis africana is used to protect a family against witchcraft but is not to be planted inside the homestead [16, 39]. The association of taboos with species that have traditionally been protected by the Vhavenda is also well documented, for example, Sclerocarya birrea are protected by the Vhavenda for their edible fruits, use as famine foods during times of hardship, medicines and shade [6]. Taboos associated with Sclerocarya birrea are enforced through beliefs such that violators or the community experience illnesses or other punishments emanating from their actions [6]. Sclerocarya birrea should not be cut down because it is believed to hold the land together and if removed will prohibit the rain from falling [16]. Only male trees of Sclerocarya birrea are cut down, and individuals face heavy fines if the tree is felled without the permission of the Khosi [39]. Taboos have continued to preserve tree species throughout Africa, for example, among the Bolero in Malawi traditional norms and practices for protecting sacred tree species have resulted in the protection of Faidherbia albida for its role in moisture retention and enhancing soil fertility for crop production during drought [40].

The Vhavenda carry out a number of practices that seek to promote sustainable harvesting practices, for example, extraction of the bark from the eastern side of a shrub or tree has also been observed among other Vhavenda researchers [6] and the Bapedi [35] due to a belief that bark harvested on this side of this tree is more potent for medicinal purposes. Other researchers have suggested that this method prevents ring barking of the tree, and because the tree receives sunlight from the eastern and western side of a tree, this supports faster healing $[41,42]$. The harvesting of only the tender leaves of selected plant vegetables and flowering of pumpkins indicating the maturity of the vegetable as observed in this study has also been documented among the Mantheding community in the Limpopo Province of South Africa [43]. The following cultural practice can also be associated with life history taboos which are applied when a cultural group bans the use of certain vulnerable stages of a species life history based on its age, sex or reproductive status [44]. In these cases, vegetables are harvested to allow them to reach maturity, bear seed and grow into the next season. The act of refilling soil over harvested roots of medicinal plants among the Vhavenda has also been observed among the Shona of Zimbabwe which is strengthened by a taboo suggesting that a failure to adhere to the practice will result in worsening sickness of the patient [45]. Other researchers have highlighted a number of taboos associated with Brackenridgea zanguebarica among the Vhavenda, for example, harvested roots or bark of this tree is prohibited from entering the homestead and women who touch the plant may experience non-stop menstruation [39]. The species is thought to cause health problems for people who harvest the roots or bark without following the correct procedures [39]. Segment taboos occur when a cultural group bans the utilisation of a species for specific time or age, sex or social status [44]. Segment taboos 
associated with women, children, menstruating females and parents of new-borns are common [44]. The prohibition of women harvesting plants during menstruation is not specific to the Vhavenda but is also encountered among African groups such as the Bapedi who believe that menstruating women will decrease the fertility of food crops, which may originate from cultural beliefs surrounding human health risks [3, 44].

Plant propagation through the cultivation of herbs and climbers and medicinal plants in home gardens has played a role in the conservation of indigenous vegetation. For example, the Kei-Apple (Dovyalis caffra (Hook.f. \& Harv.) Sim) and Oval Kei Apple (Dovyalis zeyheri (Sond.) Warb) still survive in areas of the Soutpansberg that were previously occupied by the Vhavenda [46]. Propagation of indigenous fruits and vegetables through dispersal of seeds in the homesteads for use by family members has also been observed among the Mantheding community in the Limpopo Province of South Africa [43]. However, among the Vhavenda, the motivations for plant propagation have a range of implications for the conservation of wild indigenous plants to support ecological restoration projects in the region. The various strategies employed by the Vhavenda to protect their plant resources provide in situ management methods for sustaining plant resources.

Traditional leaders in the study continue to play an important role in extending authority to monitor compliance of social norms and rules governing the harvesting of indigenous plant species. Similar roles have also been observed in other regions of the Limpopo Province where traditional leaders monitor indigenous plants use in villages through the sanctioning of fines and penalties for non-compliance $[3,43]$. Similarly, specialists such as traditional healers and female regents (Makhadzi) are significant in supporting institutional memory through the enactment of ritual ceremonies associated with plant utilisation and management. Cultural practices such as the performance of rituals to ancestral spirits through offerings of beer and food to give thanks for the year's harvests or prior to harvesting trips promote a value system that enforces a respect for all living forms. Traditionally, the Khosi or Mukoma declare the Marula season open for harvesting and it was often customary to perform a ritual before the Marula is brewed to make mukumbi, a beer [16]. Households can then brew their own beer, and samples are taken to the traditional leader for tasting which are cleansed by medicines overseen by the Makhadzi before tasting and then offered to the ancestors [19]. Thanksgiving ceremonies after the harvesting period are also performed, for example, the Makhadzi performs the thevhula ceremony where unfermented beer is poured into clay pots as an offering to the ancestral spirits [19]. The ceremony is also used to ask for appeasement in terms of other phenomena that have disturbed harmony within the community including disease, bad harvests and natural disasters and to call the rain for the next season's harvest [19]. Similar cosmological beliefs have also been observed among the Bolero in Malawi where rituals and offerings are made to God and the ancestors for rain. The cooperation of the ancestors is ensured through offerings, particularly of beer and food. When the ancestral spirits are aggrieved, usually through breaching of a moral code (or social contract), anger is believed to manifest in communal hardships through drought; therefore, rituals are held in the village to call upon the ancestors to deliver rain [40].

\section{Changing dynamics of knowledge transmission in Venda}

Plant knowledge is mainly perceived to be transmitted vertically (from parent to offspring) through 'learning by doing' from everyday interactions with relatives from helping parents to plant and harvest different species, gathering plants in the forest for food, medicines and firewood as well as preparing plant materials for meals. Other popular forms of knowledge acquisition among the Vhavenda also include oblique transmission through formal apprenticeships with traditional healers, initiation schools and clan gatherings. This follows other studies on knowledge acquisition suggesting that learning stages take place through hands-on experience and observation often reinforced through apprenticeships with knowledgeable elders $[47,48]$. From an intergenerational perspective, informants highlight the role of declining traditional platforms for knowledge exchange between elders and youth observed through the lessening of storytelling, initiation ceremonies, clan gatherings, communal rituals and ceremonies. These social mechanisms allow for cultural internalisation and as 'knowledge carriers' to enable the remembrance of rules, taboos and practices associated with plant use and management to be inculcated. Traditional cultural practices conducive to biodiversity conservation are no longer practised owing to a lack of responsibility among tribal leaders and community members to encourage the uptake of cultural practices and adherence to traditional rules and regulations as has been reported in other African studies [16, 39]. These cultural institutions play an important role in passing on institutional memory and supporting communal action; however, their decline also undermines the continuation of plant-based knowledge and management practices for utilising and protecting plant resources on communal lands.

Elders also highlight the interplay of changing value systems among the youth through the introduction of western education systems and new religious beliefs that have led to a lack of plant-based knowledge, less time spent on the land and adherence to moral codes, rituals and taboos. Formal education has been associated with 'less time spent 
in the bush' and negatively correlated with indigenous knowledge [47]. In this study, informants identified the schooling system as a causal factor driving changing value systems among younger generations as education eclipses traditional forms of knowledge transmission. Intergenerational frictions materialise through perceptions of local and indigenous knowledge as inferior to knowledge gained through formal education among the youth and observed rebellions against rules of conduct including adherence to taboos [16]. Continuity in the methods of interaction and engagement with plants and the land through the presence of knowledgeable elders and apprentices on the land is intrinsically tied with the continuity of the knowledge itself. Therefore, a lack of elders and youth engaging with the land and plants in daily life disrupts this system of knowledge acquisition. Similarly, changing religious beliefs can create epistemological and intergenerational frictions [40].

Emerging tensions are historically grounded, and our case study identifies a pattern of past colonialism and apartheid that has led to a transformation of traditional leadership structures and the introduction of new belief systems. Firstly, the youth's lack of consideration for traditional leader's authority is associated with the belief that traditional leaders complied with the demands of the National Party as a way of holding onto power; therefore, younger generations often associate these structures as entrenched in the old systems of apartheid [19]. Secondly, on the arrival of the Christian missionaries during the colonial era, their teachings aimed to acculturate the Vhavenda by advocating monotheism and depicting ancestral spirits, deities and other gods of the Vhavenda as false [19]. These frictions have demeaned local cultural practices such as consultation with ancestral spirits, traditional healing, thanksgiving rituals and myths and taboos of the Vhavenda [17]. The institution of the role of the Makhadzi is also changing, for example, few people will submit themselves to the ritual practices associated with ancestor veneration, thanksgiving and initiation ceremonies and would rather consult with Christian religious leaders for guidance [19]. The impact of these processes is too complex to unravel here but may explain some of the root causes of current tensions and barriers influencing the erosion of traditional forms of knowledge transmission.

\section{Conclusion}

The Vhavenda of South Africa maintain a complex 'knowledge-practice-belief' system surrounding the utilisation, management and protection of plant resources. The records of new plant use documented in this study and the elaboration of new uses of well-documented species are useful for providing a more comprehensive insight into the patterns and practices of plant use among the Vhavenda. Their knowledge of plant uses is extensive including a diversity of native, exotic, wild and cultivated species. Knowledge holders cultivate and collect a variety of species in home gardens cultivated lands, montane forests and deciduous woodlands demonstrating an extensive knowledge base perhaps reflecting the socio-cultural context of relative isolation and long-term settlement of the Vhavenda in the region. The dominance of indigenous plant species represented in ethnobotanical accounts suggests that plant knowledge assimilation may begin with common and readily available plants; however, the recent popularity of exotic tree species also demonstrates a form of adaptation to new introduced species that have become incorporated into the Vhavenda repository of useful plant species. Local practices and institutions are also embedded in cultural contexts and encoded in cosmologies and belief systems that have ensured the sustainable use of plant resources. Plant management strategies aim to sustain reliable and continued supply of plant resources for food, medicine and other uses through selective practices such as the prohibition of certain plants from being used, the promotion of sustainable harvesting practices and the propagation of plant species.

The research highlights the continued importance of indigenous and local knowledge for natural resource management and overcomes assumptions that local knowledge is merely anecdotal or strategic but is dynamic. The Vhavenda hold an extensive array of plant knowledge and intact belief system that is largely determined in the context of social-cultural change by how epistemological and intergenerational frictions are negotiated by individuals and communities and how different knowledge forms are largely accepted, integrated and adapted. The encouragement of hybrid knowledge co-production through the development of collaborations between state-sponsored management, conservation experts, researchers and indigenous and local knowledge holders can lessen the dominance of science and positivism as the primary decision-making frameworks for natural resource management on communal lands. The formation of new partnerships and forums for knowledge exchange between different stakeholders can open the door for more inclusive processes to explore how science and other knowledge systems can align with conservation efforts to enhance the productivity and biodiversity of communal land in South Africa.

\footnotetext{
Abbreviations

CBD: Convention of Biological Diversity; ILK: Indigenous and Local Knowledge; IPBES: Intergovernmental Platform on Biodiversity and Ecosystem Services; RFI: Relative Frequency Index; SAPIA: Southern African Plant Invaders Atlas; UVH: University of Venda Herbarium; UVI: Use Value Index
}

\section{Acknowledgements}

The authors wish to thank the Department of Science and Technology (DST), National Research Foundation (NRF) and the Sustainable Places Research 
Institute at Cardiff University for funding this postdoctoral research and the Chiefs, headmen and residents of Duthuni, Tshidzivhe, Vuvha, Lwamondo, Mashau and Tshiendeulu for their warm reception and collaboration during the development of the project. We thank Mphatheleni Makaulule for her significant role connecting NC with the Vhavenda communities through collaboration with her organisation Dzomo La Mupo and acting as a research assistant and translator during the fieldwork. We thank Mashudu Dima for his insights on Vhavenda history, traditions and plant knowledge. Finally, we are grateful to the anonymous reviewer's comments who have strengthened the content and structure of the manuscript.

\section{Funding}

The postdoctoral research was funded by the Department of Science and Technology (DST), National Research Foundation (NRF) and the Sustainable Places Research Institute at Cardiff University.

\section{Availability of data and materials}

Data on the ethnobotanical uses of plants is presented in this article in Table 1. The social data emanating from the study is available from the first author upon request.

\section{Authors' contributions}

NC conceived the study and wrote the manuscript. PT participated in its design and coordination, identified the botanical specimens and assisted with the review of the ethnobotanical literature. NC collected the data and statistical analysis. Both authors read and approved the final manuscript.

\section{Ethics approval and consent to participate}

All fieldwork was approved by the Research Ethics Committee of Cardiff University in the UK. Informant's signed agreement to participant in the study was taken as informed consent.

\section{Consent for publication}

Informant's signed agreement to publish the data emanating from this research was obtained from a signed consent form approved by the Research Ethics Committee of Cardiff University.

\section{Competing interests}

The authors declare that they have no competing interests.

\section{Publisher's Note}

Springer Nature remains neutral with regard to jurisdictional claims in published maps and institutional affiliations.

\section{Author details}

${ }^{1}$ SARChl Chair on Biodiversity Value and Change, School of Mathematical and Natural Sciences, University of Venda, Private Bag X5050, Thohoyandou 0950, South Africa. ${ }^{2}$ Sustainable Places Research Institute, Cardiff University, 33 Park Place, Cardiff CF10 3BA, UK. ${ }^{3}$ Department of Botany, School of Mathematical and Natural Sciences, University of Venda, Private Bag X5050, Thohoyandou 0950, South Africa.

\section{Received: 6 February 2018 Accepted: 13 August 2018}

Published online: 23 August 2018

\section{References}

1. Berkes F. Sacred ecology. New York: Routledge; 2012

2. Dargavel J: Indigenous forests and woodlands in South Africa: policy, people and practice, MJ Lawes, HAC Eeeley, CM Shackleton and BGS Geach, eds.: book review. Kleio 2006, 38:111-113.

3. Rasethe MT, Semenya SS, Potgieter MJ, Maroyi A. The utilization and management of plant resources in rural areas of the Limpopo Province, South Africa. J Ethnobiol Ethnomed. 2013;9:27.

4. Berkes F, Colding J, Folke C. Rediscovery of traditional ecological knowledge as adaptive management. Ecol Appl. 2000;10:1251-62.

5. Cunningham AB. Applied ethnobotany: people, wild plant use and conservation. Routledge: London \& Sterling, VA; 2014.

6. Mabogo DEN. The ethnobotany of the Vhavenda: University of Pretoria. South Africa: Department of Botany; 1990.

7. Maanda M, Bhat R. Wild vegetable use by Vhavenda in the Venda region of Limpopo Province, South Africa. Phyton Int J Exp Bot. 2010;79:189.
8. Nesamvuni C, Steyn N, Potgieter M. Nutritional value of wild, leafy plants consumed by the Vhavenda. S Afr J Sci. 2001;97:51-4.

9. Arnold H-J, Gulumian M. Pharmacopoeia of traditional medicine in Venda. J Ethnopharmacol. 1984;12:35-74.

10. Tshisikhawe MP. An ecological evaluation of the sustainability of bark harvesting of medicinal plant species in the Venda region, Limpopo province, South Africa. South Africa: University of Pretoria, Department of Plant Science; 2012.

11. Mahwasane S, Middleton L, Boaduo N. An ethnobotanical survey of indigenous knowledge on medicinal plants used by the traditional healers of the Lwamondo area, Limpopo Province, South Africa. S Afr J Bot. 2013;88:69-75.

12. Luseba D, Tshisikhawe M. Medicinal plants used in the treatment of livestock diseases in Vhembe region, Limpopo province, South Africa. J Med Plant Res. 2013;7:593-601.

13. Rampedi IT, Olivier J. Traditional beverages derived from wild food plant species in the Vhembe District, Limpopo Province in South Africa. Ecol Food Nutr. 2013;52:203-22.

14. Semenya SS, Tshisikhawe MP, Potgieter MT. Invasive alien plant species: a case study of their use in the Thulamela local municipality, Limpopo Province, South Africa. Sci Res Essays. 2012;7:2363-9.

15. Mbambala S, Tshisikhawe M, Masevhe N. Invasive alien plants used in the treatment of HIV/AIDS-related symptoms by traditional healers of Vhembe municipality, Limpopo Province, South Africa. Afr J Tradit Complement Altern Med. 2017;14:80-8.

16. Khorommbi KC. The role of Venda culture in nature conservation. A case study of the inhabitants of the Tshivhase area. South Africa: Port Elizabeth Technikon; 2001.

17. Tshiguvho T. Sacred traditions and biodiversity conservation in the forest montane region of Venda. South Africa: Clark University; 2008.

18. Stayt HA. The Bavenda. Oxford: Oxford University Press: International Institute of African Languages and Cultures; 1931.

19. Matshidze PE. The role of Makhadzi in traditional leadership among the Venda: University of Zululand. South Africa: Department of Anthropology and Development Studies; 2013.

20. Kirkaldy A. Capturing the soul: the Venda and the missionaries. Pretoria: Protea Book House; 2005.

21. Fabricius $C$, de Wet $C$. The influence of forced removals and land restitution on conservation in South Africa. Conservation and mobile indigenous peoples: displacement, forced settlement, and sustainable development. 2002;10:142.

22. Danziger C. A history of southern Africa: Indiana University. USA: Oxford University Press; 1983.

23. Fokwang JTDF. Chiefs and democratic transition in Africa: an ethnographic study in the chiefdoms of Tshivhase and Bali: University of Pretoria. South Africa: Department of Anthropology and Archaeology; 2005.

24. Vhembe District Municipality: 2016/2017 IDP review final draft. 2017.

25. Mucina L, Rutherford MC. The vegetation of South Africa, Lesotho and Swaziland. South Africa: South African National Biodiversity Institute; 2006.

26. Butt M, Everard D, Geldenhuys C: The distribution and composition of vegetation types in the Soutpansberg-Blouberg mountain complex. Report FOR DEA-814 Forestek CSIR, Pretoria, South Africa 1994.

27. Israel A. The landscape pattern surrounding the Venda sacred site of Thathe Forest. South Africa: University of Cape Town; 2012.

28. Edwards E. A broad-scale structural classification of vegetation for practical purposes. Bothalia. 1983;14:705-12

29. Richardson DM, Pyšek P, Rejmánek M, Barbour MG, Panetta FD, West CJ. Naturalization and invasion of alien plants: concepts and definitions. Divers Distrib. 2000;6:93-107.

30. Pyšek P, Richardson DM, Rejmánek M, Webster GL, Williamson M, Kirschner J. Alien plants in checklists and floras: towards better communication between taxonomists and ecologists. Taxon. 2004;53:131-43.

31. Henderson L. Invasive, naturalized and casual alien plants in southern Africa: a summary based on the southern African plant invaders atlas (SAPIA). Bothalia. 2007:37:215-48.

32. de Santana BF, Voeks RA, Funch LS. Ethnomedicinal survey of a maroon community in Brazil's Atlantic tropical forest. J Ethnopharmacol. 2016;181:37-49.

33. Masevhe NA, McGaw LJ, Eloff JN. The traditional use of plants to manage candidiasis and related infections in Venda, South Africa. J Ethnopharmacol. 2015;168:364-72.

34. Royal Botanical Gardens Kew: The state of the world's plants. 2017.

35. Semenya S, Potgieter M, Erasmus L. Indigenous plant species used by Bapedi healers to treat sexually transmitted infections: their distribution, harvesting, conservation and threats. S Afr J Bot. 2013;87:66-75. 
36. Munyati C, Kabanda TA. Using multitemporal Landsat TM imagery to establish land use pressure induced trends in forest and woodland cover in sections of the Soutpansberg Mountains of Venda region, Limpopo Province, South Africa. Reg Environ Chang. 2009:9:41-56.

37. McGregor J. Gathered produce in Zimbabwe's communal areas changing resource availability and use. Ecol Food Nutr. 1995;33:163-93.

38. High C, Shackleton CM. The comparative value of wild and domestic plants in home gardens of a South African rural village. Agrofor Syst. 2000;48:141-56.

39. Mutshinyalo T, Siebert S. Myth as a biodiversity conservation strategy for the Vhavenda, South Africa. Indilinga Afr J Indigenous Knowledge Syst. 2010;9: $151-71$.

40. Murphy C, Tembo M, Phiri A, Yerokun O, Grummell B. Adapting to climate change in shifting landscapes of belief. Clim Chang. 2016;134:101-14.

41. Magoro MD, Masoga MA, Mearns MA. Traditional health practitioners' practices and the sustainability of extinction-prone traditional medicinal plants. Int J Afr Renaiss Stud. 2010;5:229-41.

42. Kambizi L, Afolayan A. An ethnobotanical study of plants used for the treatment of sexually transmitted diseases (njovhera) in Guruve District, Zimbabwe. J Ethnopharmacol. 2001;77:5-9.

43. Rankoana SA. Sustainable use and management of indigenous plant resources: a case of Mantheding community in Limpopo Province, South Africa. Sustainability. 2016;8:221.

44. Colding J, Folke C. Social taboos: "invisible" systems of local resource management and biological conservation. Ecol Appl. 2001;11:584-600.

45. Kambizi L, Afolayan A. Indigenous knowledge and its impact on medicinal plant conservation in Guruve, Zimbabwe. Indilinga Afr I Indigenous Knowledge Syst. 2006;5:26-31.

46. von Breitenbach F, von Brietenbach J. Garcinia livingstonei orchard in Venda. J Dendrology. 1989:23-5.

47. Ohmagari K, Berkes F. Transmission of indigenous knowledge and bush skills among the Western James Bay Cree women of subarctic Canada. Hum Ecol. 1997;25:197-222.

48. Zarger RK. Acquisition and transmission of subsistence knowledge by Q'eqchi'Maya in Belize. Ethnobiology and Biocultural Diversity. Athens: University of Georgia Press. 2002;592-603.

49. Bapela MJ, Meyer JM, Kaiser M. In vitro antiplasmodial screening of ethnopharmacologically selected South African plant species used for the treatment of malaria. J Ethnopharmacol. 2014;156:370-3.

50. Samie A, Obi CL, Lall N, Meyer JJM. In-vitro cytotoxicity and antimicrobial activities, against clinical isolates of campylobacter species and Entamoeba histolytica, of local medicinal plants from the Venda region, in South Africa. Ann Trop Med Parasitol. 2009;103:159-70.

51. Rakuambo ZJ. Indigenous knowledge of bush tea (Athrixia phylicoides) and effect of fertigation frequency and growing medium on plant growth. South Africa: University of Pretoria, Department of Plant Prooduction and Soil Science; 2007.

52. More G, Tshikalange TE, Lall N, Botha F, Meyer JJM. Antimicrobial activity of medicinal plants against oral microorganisms. J Ethnopharmacol. 2008;119: 473-7.

53. Samie A, Tambani T, Harshfield E, Green E, Ramalivhana J, Bessong P. Antifungal activities of selected Venda medicinal plants against Candida albicans, Candida krusei and Cryptococcus neoformans isolated from south African AIDS patients. Afr J Biotechnol. 2010;9:2965-76.

54. Magwede K, Tshisikhawe M, Luseba D, Bhat R. Ethnobotanical survey of medicinal plants used in treatment of ticks. Phyton Int J Exp Bot. 2014;83: 155-65.

55. Mulaudzi RB. Pharmacological evaluation of medicinal plants used by Venda people against venereal and related diseases. J Ethnopharmacol. 2012;135: 330-7.

56. Mulaudzi R, Ndhlala A, Van Staden J. Ethnopharmacological evaluation of a traditional herbal remedy used to treat gonorrhoea in Limpopo province, South Africa. S Afr J Bot. 2015;97:117-22.

57. Todd C. Mutavhatsindi. Veld \& Flora. 1999;85:17.

58. Netshiungani A. Mutavhatsindi-mysterious plant from Venda. Veld \& Flora. 1980;66:87.

59. Arnold T. Comments on primitive South African crop sorghums and the evolution of sorghum races in Africa. Bothalia. 1983;14:587-94.

60. Samie A, Obi C, Bessong P, Namrita L. Activity profiles of fourteen selected medicinal plants from rural Venda communities in South Africa against fifteen clinical bacterial species. Afr J Biotechnol. 2005;4:1443-51.

\section{Ready to submit your research? Choose BMC and benefit from:}

- fast, convenient online submission

- thorough peer review by experienced researchers in your field

- rapid publication on acceptance

- support for research data, including large and complex data types

- gold Open Access which fosters wider collaboration and increased citations

- maximum visibility for your research: over $100 \mathrm{M}$ website views per year

At BMC, research is always in progress.

Learn more biomedcentral.com/submissions 